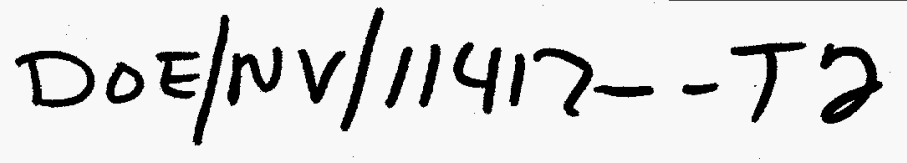

\author{
ANNUAL REPORT ON PALEOCLIMATE STUDIES \\ FOR THE YUCCA MOUNTAIN PROJECT SITE CHARACTERIZATION \\ CONDUCTED BY THE DESERT RESEARCH INSTITUTE FOR \\ THE DEPARTMENT OF ENERGY \\ Prepared by \\ Personnel of the Quaternary Sciences Center
}

\title{
INTRODUCTION
}

\section{Site Requirements:}

The prospect that Yucca Mountain may become a repository for high-level radionuclides with especially long half-lives means that the intended waste containment area must be well beyond the reach of the hydrologic system for at least ten millennia. Assessment of site suitability and design appropriateness requires clear understandings of the directions, magnitudes and rapidity of climate changes and their impact upon ground water regimes. Because historic climate records indicate very little regarding the possible range of climate even during the last 500 years. full understanding of the possible impacts of future climate change requires knowledge not only of the range of modern climates, but also of past climates. In particular, patterns of past climate variation must be explored in order to reveal not only the possible range of mean climate, but also the potential extremes that may reasonably be expected during the next 10,000 years or so at which time stored materials will have decayed sufficiently to render them harmless. Although studies of orbital mechanics provide speculative notions of future climatic trends. they cannot be used to predict how these trends will manifest themselves in the immediate vicinity of Yucca Mountain. or even, at present, in the Intermountain West. In order to address these concerns, conditions under which extremes of wetter climate have occurred during the late Quaternary (the last 200,000 years or so) must be considered and used as a guide to the likely range of future climate variation.

\section{Project Goals:}

The goals of the studies being conducted by the research staff of the Quaternary Sciences Center at the Desert Research Institute are two pronged. Through the integration of several avenues of paleoclimatic proxy data. we intend to arrive at definite conclusions regarding rates of change, and extremes and stabilities of past climate regimes. These will in turn lead to rough estimates of :

- 1.) the amounts of rainfall available for recharge during past periods of effectively wetter climate

- 2) the durations and frequencies of recharge periods

These may in turn be used to estimate the possibility that such events may occur in the future. This information can then be used by the geohydrologist to provide estimates of:

- 1) ground water movement through the unsaturated zone

- 2) how much and how rapidly the upper surface of the saturated zone may fluctuate through time. 


\section{DISCLAIMER}

This report was prepared as an account of work sponsored by an agency of the United States Government. Neither the United States Government nor any agency thereof, nor any of their employees, make any warranty, express or implied, or assumes any legal liability or responsibility for the accuracy, completeness, or usefulness of any information, apparatus, product, or process disclosed, or represents that its use would not infringe privately owned rights. Reference herein to any specific commercial product, process, or service by trade name, trademark, manufacturer, or otherwise does not necessarily constitute or imply its endorsement, recommendation, or favoring by the United States Government or any agency thereof. The views and opinions of authors expressed herein do not necessarily state or reflect those of the United States Government or any agency thereof. 


\section{DISCLAIMER}

Portions of this document may be illegible electronic image products. Images are produced from the best available original document. 
To accomplish these goals the paleobotanical and paleozoological record are being examined to identify periods of greater effective precipitation. Index plant and animal species are then used to constrain the temperature and precipitation ranges that occurred during those periods. Additional corroboration and precision of these estimates are being obtained through the study of stable isotopes from these biotic remains. Because established biotic communities can assimilate much of the water that arrives during a period of mesic climate. geomorphic (alluvial. fluvial and lacustrine) analyses are being conducted in order to provide estimates of excess water availability. Aeolian geomorphic evidence is being used to provide 1) estimates of surface exposure. an indirect measure of vegetation density (a strong factor affecting rainfall interception), and 2) as a measure of lake level fluctuation and fluvial activity (aeolian dunes obtain most of their supply of sand from unvegetated playas and river channel deposits).

Clearly it is not enough to study only one or two aspects of the ecosystem in order to reconstruct past climate. Each factor feeds back into the system and thereby affects other parts of the system. In this way the amount of precipitation actually available for recharge may vary considerably even under the same rainfall regime.

An additional dimension of our investigations has involved paleoenvironmental studies conducted in several areas of the Great Basin. We are collecting information that will indicate the position of the polar front along a north south transect ranging from southern Oregon through southern Nevada, the potential range of variation in its position during the late Quaternary. These studies provide us with understandings of the location of the polar front (which governs the westerly storm track) during the winter as well as the summer for the Pleistocene and the Holocene. Shifts in the position of the westerly storm track governed the nature of past rainfall. including not only its seasonality and amount. but also its duration and intensity. Each of these factors effected ground water recharge differentially.

Finally, although we presently are focusing upon the proxy climate record of the late Holocene, Pleistocene proxy climate studies are ongoing. We have done this initially in order to arrive at clear understandings of the relationships between the targeted paleoclimatic proxy data and modern and near recent climates. These may lead to the development of transfer functions that may be used when the less robust and sparser paleoclimatic proxy data of the Pleistocene are being examined. In addition. study of the more recent record will give us an understanding of the possible ranges of climate under late Holocene conditions... a period that has been characterized by variations of shorter duration. but of almost as great climate extremes as during the Pleistocene. In the current year we. will focus our efforts in the White River Valley north east of Las Vegas. We will conduct paleobotanical and geomorphological studies to illuminate the relationships between climate, vegetation response and cycles of erosion and deposition. These linkages should be made clear in the high resolution paleoclimatic proxy record of the Pahranagat lakes area.

During the later phases of the project or if funding increases we intend to shift our emphasis to the Pleistocene record. Among the efforts that we are undertaking with regards to the Pleistocene data set is a direct dating of indicator plant species from other woodrat middens that have been analyzed by previous investigators. These dates will confirm the actual time of the occurrence of these species. Currently many of these species are assigned radiocarbon ages based upon the dates obtained on associated materials. The possibility of cross contamination of middens of various ages with materials from older and younger nests is well documented. Direct dating of indicator species will confirm or disprove previously suggested associations. Arrangements have already been made to redate much of the material from middens in and around the Nevada Test Site.

Below we have assembled a brief summary of the findings of our first year of research. 
SECTION 1:

LATE QUATERNARY AND HOLOCENE CLIMATE DERIVED FROM VEGETATION HISTORY AND PLANT CELLLLOSE STABLE ISOTOPE RECORES FROM THE GREAI BASIN OF WESTERN NORTH AMERICA

\section{Prepared by}

Peter E Wigand

and Martha L Hemphill. Saxon Sharpe and Sikha (Manna) Patra of the Quaternary Sciences Center, Desert Research Institute. P.O. Box 60220. Reno, Nevada 89506, (702)673-7387. pwigand@wheeler.maxey.unr.edu

\section{Project Goals}

Paleobotanical studies are being used to reconstruct the community and organismal level responses of vegetation to past climate. Periods of mesic climate during the last 20.000 to 50.000 years in the Yucca Mountain region are being identified. Estimates of their magnitude are being derived through modern analogue comparisons and assessment of their various other environmental impacts. This is being achieved by 1) integrating data obtained from nearly continuous records of pollen from lacustrine and playa sediments and from 2) plant macrotossils. pollen and stable isotopes from fossil woodrat middens.

These data will be used to identify periods of much more mesic climate. They provide information that can be used to estimate the magnitudes and durations of rainfall shifts by reference to modern distribution. characteristics and ecophysiology of analogous plant communities and/or indicator species. Of particular importance is determination of the amounts. and actual duration of the availability of excess water during these periods. These estimates. in combination with those derived from ostracode and diatom analyses conducted by the
LSGS wiil provide reasonable indications of variations in vilimate that can be used to reconstruct past extremes in available precipitation. These may serve as estimates of conditions that ure possible during the next 10.000 years at Yucca Mountain.

Evidence of periods of increased erosion related to increased runoff derived from the geomorphologicai studies will be linked with paleozoological data to refine estimates of the duration and magnitudes of such excess water availability. Linked in this way, estimates of climate derived from the terrestrial environment can be compared with those derived from lacustrine environments to arrive at secure inputs for hydrological models of recharge.

Results

One method for estimating the past climate of a region is to examine its vegetation history. Although other proxy data sets. e.g., diatom and ostracode. can be used to reconstruct detailed lacustrine. riparian and spring discharge histories and relate them to regional precipitation, reconstructed terrestrial vegetation provides additional information crucial for determining the conditions under which past ground water recharge occurred. Knowledge of the type, distribution. and density of past vegetation communities aids in assessing the impact of evapotranspiration and plant uptake on the amount of water that may be available for recharge.

Typically, in the arid West reconstructed climate history has been based upon analyses of pollen from stratified deposits in lakes, marshes and alluvium. and upon plant remains preserved in ancient woodrat nests (middens). Paleobotanical data are used to reconstruct changes in plant community composition which reflect general trends in changing precipitation and temperature. ${ }^{1.2 .3}$ Whereas woodrat midden studies concentrate on the appearance and disappearance of specific indicator species that characterize 
changing piant communities. anairses of poilen records resuit in the reconstruction of long-term. relatively continuous, shifts in the gross composition of plant communities. In part. this locus has been dictated by the techniques that have been available to investigators. and by issues of time and money.

During the last two decades. techniques more amenable to the investigation of past plant response to climate change at the organismal level have been inaugurated in paleobotanical anaiyses. These extend our ability to understand plant community history, and to reveal answers regarding differences and/or similarities in the physiological response of plants during the Holocene and the Pleistocene. ${ }^{+56.7}$ Integration of past and ongoing research on vegetation histories derived from Great Basin pollen and woodrat midden records reveal large scale changes in temperature and precipitation both in northern and southern Nevada.

Holocene Analogues And Pleistocene Records

\section{Pollen and Plant Macrofossil Records}

Thus far, our currently researched pollen records from the Oasis Valley northeast of Beatty, Nevada and Lower Pahranagat Lake south of Alamo. Nevada. and those of P. J. Mehringer from Tule Springs in the Las Vegas Valley and from samples collected by him in Ash Meadows west of the Spring Range form the basis of relatively continuous late Holocene and intermittent Pleistocene reconstructions of vegetation history around the Nevada Test Site. ${ }^{7.9}$ Regional terrestrial pollen and the pollen of local littoral and aquatic plants indicate periods of both local and regional vegetation change and local water table fluctuation in response to climate change during the last 2.000 to 6.000 years. Fluctuations in juniper and pine pollen in the well-preserved record from Lower Pahranagat Lake reflect variation in winter precipitation, and in particular is impact in intermediate elevation forests. Juniper poilen values vary between 5 and 22 percent. These values reflect major changes in distribution. density and productiviry of juniper on the landscape and. in fact. suggest that juniper may have grown signiricantly nearer Lower Pahranagat Lake until around 2.000 b.p.? This would indicate a drop in lower tree-line of one to two hunared meters. Woodrat midden data from the Sheep Range south of the lake suggests that there may have been as much as a $200 \mathrm{~m}$ depression in lower tree-line centered between 2.000 and 4.000 years b.p. ${ }^{10.11}$ Reconstructed deposition rates of the high resolution Lower Pahranagat Lake record (a sample every 14 years for the last 2.000 years) suggest that at times the transition to higher juniper poilen values may have taken only a few decades. The local increase in effective precipitation necessary to accomplish this change, based upon the difference in the minimal annual rainfall requirements between Sagebrush ${ }^{12}$ and Utah Juniper. ${ }^{13}$ must have been at least 10 to $20 \mathrm{~mm}$ per year and could have been as much as $70 \mathrm{~mm}$ per year. Reduced evaporation rates due to reduced mean annual temperature may have played a significant role in increasing effective precipitation.

At Lower Pahranagat Lake, three additional increases in juniper pollen, indicating greater effective precipitation resulting from increased winter precipitation and reduced evaporation rates. occur between 1.500 and 1,100 b.p.. about 700 b.p. and about 300 b.p. (Figure 1). Although these are not as significant as the one ending about 2.000 b.p. they are mirrored by the pollen record from Cofer Spring north of Beatty, Nevada. ${ }^{14}$ Further evidence for these increased precipitation events is recorded in the sequence of dune and peat layers from Ash Meadows. ${ }^{9}$ Although complicated by dune movement and the possibility of neo-tectonic activity, the formation of these peat strata reflect increased discharge of the major springs in Ash Meadows during four 
errods of peat formation spanning the past $\$ .300$ : ears b.p.: 1) between 5.300 and 4.450 b.p.: $z)$ between 4.000 and 3.600 b.p.: 3$)$ about 3.000 b.p.; and 4) about 400 b.p. Of these. the last can be correlated with the records obtained from Lower Pahranagat Lake and Coter spring. it Warm Sulphur Springs in the Panamint Valley, California sedge seeds from a peat dated to $3.400 \pm 500$ b.p. and from one dated to c. 220 b.p. These record two episodes of peat growth that reflect periods of increased effective precipitation from other southem Nevada records. ${ }^{4}$ Additional corroboration of these events is provided by the record from Little Lake in the Owens Valley south of Bishop, California. Here periods of greater effective precipitation during the past 4.000 years roughly span the periods from about 2.800 to 2.000 b.p., from 1,900 to 1.500 b.p., from about 1150 to 700 b.p., and since about 350 b.p. ${ }^{15}$ Unfortunately, old ground water carbon contamination of datable materials from those pollen cores precluded a formulation of good chronology with the radiocarbon techniques of the time (today AMS dating can be used to obtain dates on small samples that have terrestrial origin in such sediments and are therefore uneffected by ground water contamination). It is clear. however. that there have been at least four late Holocene periods of regionally increased effective precipitation during the last 4.000 years in the southern Great Basin.

Just how extensive these events were can be resolved through a comparison with the record from Diamond Pond in the Harney Basin of southcentral Oregon in the northern Great Basin. ${ }^{16}$ Although over 1300 kilometers farther north, it is well dated and the correspondence of wet and dry periods with those identified in southern Nevada is surprising. Using the ratio of aquatic to littoral plant macrofossils at Diamond Pond as an accurate indication of water table fluctuations and regionally increased effective precipitation. the timing of wet periods are as follows: 1) between ca. $3 . .50$ and $\$ . \$ 50$ b.p.. 2$)$ ca. 2.800 to 2.600 b.p. 3 from 2.250 to 2.050 b.p. 4 ) from 1.000 to 800 b.p. and 5 ) from 300 to 150 b.p. (Figure 2). Except for the period ca. 2.800 to 2.600 b.p., these events correspond closely with those of southern Vevada. However. following the 5.300-year b.p. amelioration of middle Holocene drought conditions--recorded as far north as Wildcat Lake in the Columbia Plateau of Washington State ${ }^{17}$ and as far south as Ash Meadows, Nevada ${ }^{9}$--the most significant event in all these records is the one centered around 3.600 b.p. This appears to be the interval of greatest "Neoglacial" effective precipitation increase. This period corresponds to extensive marsh expansion in the northern Great Basin as evidenced in the archaeological records of caves and marsh margin sites. ${ }^{18}$

Additional support for these conclusions is found in the sudden increase in abundance of woodrat middens during these periods of wetter climate both in the northern Great Basin ${ }^{6,19}$ and southern Nevada. ${ }^{20}$ and in greater effective precipitation recorded in the tree-ring records from the White Mountains at 3,300 b.p., between 2,300 and 1,900 b.p., about 800 b.p. and during the last 200 years. ${ }^{21}$

The abundance of data that is currently available for the late Holocene is in contrast to the relative dearth of data from the late Pleistocene. Although abundant woodrat middens are available for certain portions of the period between 45,000 vears b.p. and the present, other periods are greatly unrepresented (Figure 3). Ancient woodrat middens indicate that significant changes occurred in plant community composition at the end of the Pleistocene.

A comparison of the valley floor record from Lower Pahranagat Lake when compared with the valley floor record from Tule Springs in the Las Vegas Valley ${ }^{3}$ reveals the dramatic difference in vegetation response between late Holocene and Pleistocene wet periods (Figure 3). During the late Holocene (the last 2000 years is 
trom Lower Pahranagat Lakel the hignest proportion of pine and iuniper to saitbusin attained is only $1 / 50$ of that winch occurred during the more extreme portions of the Pleistocene the pollen vaiues in Figure 3 from 0.000 b.p. back to 45.000 were derived from the Tule Springs work of Mehringer ${ }^{\circ}$ ).

This difference reflects primariiy an increase of pine on the landscape and a deciine in the abundance of the saitbusines which predominate much of the modern landscape in the valleys surrounding the Nevada Test Site. Based upon the woodrat midden record much of the increase in pine pollen values resulted from the increased areal coverage of Limber Pine (Pinus flexilis) when its elevational distribution lowered by as much as 1.000 meters (Figure 4). ${ }^{10.11}$ Limber Pine needles are common in the woodrat middens that have been recovered from the Nevada Test Site. These record the presence of Limber Pine at 2133 meters in the Belted Range at 18,000 b.p., 1525 meters in the Ribbon Cliffs at the NW corner of the Nevada Test Site at 18.000 b.p. and at 1950 meters in Stockade Wash on the south side of Rainier Mesa at 18,000, 16,000 and 12,000 years b.p. In the southern Pahranagat Range Limber Pine is indicated at 1685 meters at 18.000.16.000 and 12.000 years b.p. and in the central Pahranagat Range at 1600 meters at 12.000 b.p. (Figure 4). This is in agreement with other evidence that indicates Limber Pine occurrence between 1500 and 1300 meters in the Sheep Range between 20.000 and 18.000 b.p. ${ }^{16}$ and at 1900 meters on Clark Mountain south of the Spring Range around 23.000 b.p. and again at 12.000 b.p.: $=$

The past presence Limber Pine woodland (occasionally mixed with Mountain Mahogany, Cercocarpus ledifolius) in areas that today are dominated by pinyon-juniper woodland indicates a significant shift in climate. Based upon data retrieved from the U.S. Forest Service's SCS DATA BANK in Fort Collins, CO. the climate shiti is rom todays regime or about 200 to 250 $\mathrm{mm}$ mean annual precipitation (MAP) and an annual temperature range of from -10 to $35^{\circ} \mathrm{C}$ to a Pleistocene regime of from 380 to $560 \mathrm{~mm}$ MAP and an annual temperature range of -51 to $36^{\circ} \mathrm{C}$ (based upon the climatic constraints of Utah Juniper versus Limber Pine).

This shift is exceeded around 23,000 b.p. by conditions that evidence the onset of the last major Wisconsin glacial stade. At 23,000 b.p. White Fir (Abies concolor) occurs down to 1695 meters in our own woodrat middens in the Pahranagat Range, and down to 1900 meters on Clark Mountain by 22,000 b.p. (Figure 4). ${ }^{22}$ A similar event occurs around 13.000 years ago in both the Clark Mountain and Pahranagat Range woodrat midden records (Figure 4).

Again based upon data retrieved from the U.S. Forest Service's SCS DATA BANK in Fort Collins, CO. a potential climatic shift is indicated in an area currently dominated by pinyon-juniper woodland with a regime of from 200 to $250 \mathrm{~mm}$ MAP and an annual temperature range of -10 to $35^{\circ} \mathrm{C}$ to a Pleistocene regime of from 760 to 1910 mm MAP but a potential annual temperature range of -34 to $43^{\circ} \mathrm{C}$. This may be up to a two to four fold increase in regional MAP in the Nevada Test Site region.

The elevational depression in the distribution of White Fir is also documented in the Tule Springs pollen record (the only one currently available for this period of time). Prior to 22,000 b.p. in the $D$ stratigraphic unit. fir pollen increases to about two percent of the record. This is significant considering that almost 85 percent of the pollen record at the same time is dominated by pine pollen. ${ }^{8}$ Values of fir pollen of almost six percent indicating even greater abundance of White Fir on the landscape occur in Unit B sediments of the Las Vegas Valley prior to 37,000 years ago. Thus far, few well dated woodrat midden strata exist that cover this earlier period of time to corroborate this expansion. 
isecond expansion of White tir to simiiar sievations centered around $: 2.000$ b.p. is evidenced in middens collected by us last summer in Stockade Wash and in the Pahranagat Range and by plant macrofossiis from middens collected by Mehringer and Ferguson on Clark Mountain.: When viewed together with the Limber Pine expansion. the periods of White Fir expansion seem to characterize the onset and end (but not the main portion) of the last glacial stade. These two periods also coincide on the regional scaie with the two high lake stands of pluvial Lake Lahontan (Figure 4).

Although the pollen and macrofossil data discussed to this point indicate the net effects of long-term increased effective precipitation. evidence derived from stable carbon isotopes may eventually provide more detailed information regarding the rapidity of climate change and the span of time during which excess rainfall may have been available for ground water recharge.

\section{Stable Carbon Isotope Climatic Signals In Plants}

Studies of respiration. chemical absorption of $\mathrm{CO}_{2}$, and $\mathrm{CO}_{2}$ diffusion as mechanisms of isotopic fractionation in plants led to the recognition of variability in the content of ${ }^{13} \mathrm{C}$ in plants.3.24.25.26.27.28 These and other studies demonstrated that significant variation in carbon isotopic fractionation in plants (i.e., differences between $\mathrm{C}_{3}, \mathrm{C}_{4}$ and $\mathrm{CAM}$ plants) occurred as a result of differences in piant metabolism. It was not until the early 1980s that study of the biochemical and physiological basis for these differences began in earnest. ${ }^{29}$ It was found that within these groups $\left(\mathrm{C}_{3}, \mathrm{C}_{4}\right.$ and $\mathrm{CAM}$ plants). within the same species and even within the same organism differences in $\delta^{13} \mathrm{C}$ occur that are conditioned by organismal response to environmental conditions.

In order for plants to grow they fix carbon that enters through leaf pores (stomata) as $\mathrm{CO}_{2}$. Increased conductance of leaf stomata causes an increase in the partial pressure of $\mathrm{CO}_{2}$. However. the resuitant increase in the rate of $\mathrm{CO}_{2}$ assimilation must be balanced with the increased rate of transpirational water loss. ${ }^{30}$ It is this need to balance these two factors that results in fractionation of stable isotopes of carbon in the plant.

Variation in isotopic fractionation of carbon in plants is due to several environmental parameters. Among these are: 1) habitat soil water content. ${ }^{31,32.33}$ 2) atmospheric humidity, ${ }^{34} 3$ ) annual precipitation in dry localities, ${ }^{31}$ 4) exposure to light, ${ }^{31.32 .35 .36} 5$ ) atmospheric $\mathrm{CO}_{2}$ stratification, ${ }^{37.38}$ or combinations of the latter two, ${ }^{39} 6$ ) season of measurement, $^{31}$ 7) differences in mean annual temperature..$^{40}$ and. perhaps. 8) differences in stomatal density. ${ }^{41.42,43.44,5}$

Within the Great Basin the relative percentages of tree pollen as well as influx estimates of these species when they are available suggest that woodlands remained relatively open throughout the Pleistocene. Therefore, factors such as exposure to light and atmospheric $\mathrm{CO}_{2}$ stratification through lack of canopy level mixing of air probably did not play a major role in $\delta^{13} \mathrm{C}$ enrichment: Although occasional increases in atmospheric humidity may have effected $\delta^{13} \mathrm{C}$ enrichment. drought and low temperature enrichment of $\delta^{13} \mathrm{C}$, and perhaps changes in atmospheric $\mathrm{CO}_{2}$ content were probably the major factors governing enrichment.

Given these constraints, our initial research suggests that the $\delta^{13} \mathrm{C}$ data on whole plant material collected from woodrat middens in the Great Basin indicate that drought and low temperature have acted in concert at differt time scales during the late Quaternary in effecting $\delta^{13} \mathrm{C}$ enrichment in plant materials. A plot of $\delta^{13} \mathrm{C}$ values of plant materials from strata of a single woodrat den in the Virginia Mountains of NW Nevada reveal enrichment trends contrary to those for the drought induced water stress expected from the reconstructed climatic trends of the last 
$\$ 0.000$ years (Figure $5 \%$ in this case. I poiynomial curve tit of the $0: \mathrm{C}$ vaiues of plant materiais. which are normaily considered to be a measure of plant water use efficiency. show remarkable similarity to late Quaternary temperature variations suggesting that temperarure may be a strong long-term influence. A similar conclusion can be drawn from a best fit curve plotted against the $j^{13} \mathrm{C}$ values of materials obtained from woodrat midden strata sampled regionally around the pluvial Lake Lahontan basin (Figure 6).

Therefore, long stable isotopic records from a single locality mirror the massed data from an entire region. Both reflect the long-term effect of temperature. whereas short-term outliers (the apparent noise) probably reflect increased water use efficiency as a result of "real" droughts. The long-term regional temperature pattern can be extended with a comparison of the $\delta^{13} \mathrm{C}$ values from the Virginia Mountain midden in NW Nevada and the values obtained by Siegel from North Snake Range middens in eastern Nevada (Figure 7). This similarity can be extended to southern Nevada as well (Figure 8).

Well-dated fossil pollen records from continuous lake sediment cores are being analyzed to corroborate the conclusions drawn from both the stable isotope and midden plant macrotossil records. Pollen records are the only certain way in which the direction, magnitude and duration of vegetation changes can be verified. Clear corroboration of the conclusion that long-term $\delta^{13} \mathrm{C}$ enrichment is driven by temperatue is provided by the effective rainfall ratio generated by the pollen record from Lower Pahranagat Lake over the last 2,000 years (Figure 9). Increased proportions of pine and juniper poilen verses saltbush pollen types reflect vegetation community response to greater effective precipitation. In this case, increased ratio values correspond to the terminal "Neoglacial". the late Roman period and the "Little Ice Age", all well recognized periods of cooler climate with effectiveiy greater precipitation (Figure 9).

Theretore. long-term trends in $\delta^{13} \mathrm{C}$ when compared with the vegetation record in the Great Basin. reveal that periods of wetter-climate vegetation correspond to more positive $\delta^{13} \mathrm{C}$ values or enrichment driven by temperature despite the presence of more moisture. Increased water use efficiency may, in this case. be triggered by "drought" as induced through water being tied up as ice in the ground during the growing season (shortened growing season). ${ }^{40}$

Increased $\mathrm{C}^{13}$ enrichment could also occur during periods when cold spring temperatures would force the growing season later into the year, well after most of the annual rainfall occurred. However, if this were the case the shift from dry to wet plant community species should not occur. If anything, a shift in the opposite direction in plant community species composition would be expected.

Although most short-term trends seem to reflect "real drought" resulting from decreased rainfall, ${ }^{45}$ there are short-term fluctuations that are not so easily explained. The resolution of these contradictions may lie in the competition of individual plants for water within the plant community in a desert environment.

Plants adapted to the semi-arid climates of the Great Basin have a tremendous capacity to respond to increased water availability with dramatic increases in biomass production, e.g., those that characterized the period of increased rainfall during the early 1980s. If more water is available then can be assimilated by plants through increased size, new plants will grow and fill the spaces between the older plants. If still more water is available. a shift to new plant species occurs resulting in the community composition changes that typify the last 40,000 years of the woodrat midden record. Under these new conditions even more water can be assimilated. However, because these species have 
:o migrate into the area. a lag time occurs between ciimate change and the establishment of the new plant community. Eventually, the new plant community will form and through plant size and plant spacing the excess water will be assimilated by this new community.

When development of the new plant community is complete competition for available water again becomes acute. aithough at a higher level reflecting the greater availability of water and the greater requirements of the new community. Therefore, although pollen and plant macrofossil materials indicate that the wetter climate vegetation still predominates, plant water stress induced by the competition for water becomes the driver of $\delta^{13} \mathrm{C}$ enrichment. Under these conditions the community becomes susceptible to disturbance phenomena. such as disease, insect infestation and fire which eventually will destroy the more mesic plant community species and replace them with shrubs and forbs that are less water demanding and are less stressed by the competition for water. These plants will have less enriched values of $\delta^{13} \mathrm{C}$.

During the transition from arid-plant community to a completely developed wetterclimate community, increasing water use efficiency (as reflected by $\delta^{13} \mathrm{C}$ enrichment) reveals the decreasing availability of excess water as it is utilized by plants. This excess water is what will be available for both runoff and recharge during wet periods. Therefore. it is these transitional periods that should be monitored to determine the amount of water that may be available for movement through the aquifers of southern Nevada.

Varying competition for water of plants during the transitions from drier to wetter plant communities may account for some of the unexplained variation that is clear in the $j^{13} \mathrm{C}$ value records from the northern Great Basin during the last 4,000 years (Figure 10). The ratio of juniper to grass pollen from Diamond Pond indicates periods of wetter climate juniper Sominance). variations in $0^{13} \mathrm{C}$ reflect the cold temperatures of the "Neoglacial" post 1,000 b.p. period and the "Little Ice Age." charcoal values indicate the increase in regional fires once juniper woodland became weil established and susceptible to drought period fires. A similar pattern occurs in southern Nevada with a comparison of the Lower Pahranagat Lake pollen and charcoal records and the $\delta^{13} \mathrm{C}$ values obtained from local middens (Wigand unpublished).

These data may potentially allow estimates of 1) the time span when excess water was available, 2) its initial amount and 3) its decline as competition for water among plants began to reduce its availability. There is a consistent pattern that can be observed in determining these periods.

Initially, the onset of wetter climate--even before the plant community composition has changed--will be revealed by both increased pollen production (more pollen per square centimeter per year) and by a sudden brief decrease in the $\delta^{13} \mathrm{C}$ content of plant materials sequestered in the contemporaneous woodrat middens. As the plant community responds with increased biomass production and introduction of new species. the water availability will decrease and relative $\delta^{13} \mathrm{C}$ enrichment will increase as plants attempt to conserve the increasingly sparser resource. Maximum relative enrichment values should occur when the new community has maximized its use of the available water. At this point little or new water will be available for recharge. Obviousiy, there will be short-term fluctuations in response to wet and dry years, but the long-term indication in the stable isotopic record will reflect the impact on water availability caused by acute competition of the "climaxed" vegetation for that resource. It should be recognized that $\delta^{13} \mathrm{C}$ values of the "climaxed" vegetation are still less positive than those that would occur during a severe drought. They are 
-nriched oniy relative to what they would be if the community still had excess water available. From il: $\mathrm{C}$ values of shrub materiais in the same midden itrata as the tree materiai it is ciear that shrubs are uss stressed than trees at the same time. Ylost of the shrub species are those rypicaliy found in cirier communities and would be more drought tolerant than would the more mesic community tree species by decreases in errective precipitation or competition.

In conclusion, the amount of water available for recharge during the transition from drier to wetter plant communities in general should approximate the difference in rainfall between the more mesic and more reric vegetation communities that were replaced. The span of time between the first indication of changed climate and the point when water use efficiency is greatest ( $\delta^{13} \mathrm{C}$ values are greatest) in the new plant community is the period when excess water would be available for groundwater recharge or surface discharge. The decreasing amount of water available through time is probably inversely proportional to the increase in water use efficiency as reflected in the $d^{13} \mathrm{C}$ values of the plant record. The relationship of climate, productivity and competition for resources reflected in these paleoenvironmental proxy records reflect those already cleariy understood and accounted for in dendroclimatology. ${ }^{46}$

Conclusions

Late Holocene changes in plant community composition in both northern and southern Nevada reflect periods of effectively moister climate: These intervals are generally coincident with regrowth of Great Basin marshes and increased spring discharge. i.e.. $\sim 3.600$ b.p.. from 2.300 to 1,900 b.p., $\sim 1.000$ b.p. and $\sim 350$ b.p. Variations in the proportions of stable isotopes of carbon in radiocarbon dated plant materials from fossil middens apparently provide a means of gauging the rapidity of vegetation
Wsponse to increased water availability at the organismai levei. In addition. such variations provide a means of determining the duration and umount of water available for recharge during the transitions from one vegetation type to another. These can be imperiaily tested with modern analogue studies. Midden records from Pleistocene woodrat middens aiready have led to new understandings regarding $0^{13} \mathrm{C}$ enrichment and its relationship to temperature. Documentation with new evidence of Pleistocene lower tree-line depressions indicate significant regional increases in precipitation at 24,500 to 22.000 b.p. and between 14,000 and 13,500 b.p.

As the late Pleistocene woodrat midden and woodrat midden stable isotopic record and regional pollen sequences are expanded, periods coincident with the onset of wetter conditions will be examined using these methods. As a result better estimates of the actual amount of water available for runoff and recharge should be possible.

\section{References}

1. P. J. Mehringer, Jr., Late-Quatemary pollen records from the interior Pacific Northwest and northern Great Basin of the United States. pp. 167-189. in V. M. Bryant. Jr. and R. G. Holloway (eds.). Pollen Records of Late-Ouaternary North American Sediments. American Association of Stratigraphic Palynologists. Dallas (1985).

2. P. J. Mehringer. Jr., Prehistoric environments. pp. 31-50. in W. L. D'Azevedo (ed.), Volume 11: Great Basin, Handbook of North American Indians, Washington. D.C. (1986).

3. J. L. Betancourt. T. R. Van Devender and P. S. Martin (eds.), Fossil Packrat Middens: The Last 40.000 Years of Biotic Change, University of Arizona Press, Tucson (1990). 
$\therefore \quad$ A. Long. L. A. Warneke. L. L. Betancourt and R. S. Thompson. Chapter 17 : Deuterium variations in piant cellulose from fossil packrat middens. pp. 380-396. in J. L. Betancourt. T. R. Van Devender and P. S. Martin (eds.). Fossil Packrat Litddens: The Last 40,000 Years of Biotic Change. University of Arizona Press. Tucson (1990).

ミ. P. K. Van de Water. Ecophysiological response of Pinus flexilis to atmospheric $\mathrm{CO}_{2}$ enrichment during deglaciation. Unpublished M.S. thesis. University of Arizona, Tucson (1993).

6. P. J. Mehringer, Jr. and P. E. Wigand. Comparison of Late Holocene environments from woodrat middens and pollen: Diamond Craters, Oregon, pp. 294-325. in J. L. Betancourt. T. R. Van Devender and P. S. Martin (eds.), Fossil Packrat Middens: The Last 40,000 Years of Biotic Change, University of Arizona Press. Tucson (1990).

7. P. E. Wigand and M. K. Rose. Calibration of high frequency pollen sequences and treering records, in Proceedings of the International Highlevel Radioactive Waste Management Conference and Exposition, April 8-12, 1990. American Nuclear Society, La Grange Park. Illinois (1990).

-8. P. J. Mehringer, Jr.. Pollen analysis of the Tule Springs area, Nevada. in H. M. Wormington and D. Ellis (eds.), Pleistocene Studies in southern Nevada. Vievada State Museum Anthropological Papers 13. Carson City, Nevada (1967).

9. P. J. Mehringer, Jr. and C. N. Warren. Marsh. dune and archaeological chronology, Ash Meadows, Amargosa Desert. Nevada. pp. 120-150. in R. G. Elston and P. Headrick (eds.), Holocene Environmental Change in the Great Basin. Vevada Archeological Survey Research Papers 6, Reno (1976).

10. W. G. Spaulding, The late Quaternary
Vegetanion or a southern Nevada mountain range. unpubiished Ph.D. dissertation. University of Arizona. Tucson. pp. 271 (1981).

11. W. G. Spaulding. Vegetation and climates of the last +5.000 years in the vicinity of the Nevada Test Site. south-central Nevada, U.S. Geological Survev Professional Paper 1329. pp. 83 (1985).

12. H. N. Mozingo, Shrubs of the Great Basin: a Natural History. University of Nevada Press. Reno (1987).

13. S. Leonard. R. Miles and H. Summerfield, Soils of the Pinyon-Juniper woodlands, pp. 227-230. in R. Everett (ed.), Proceedings Pinyon-Juniper Conference, Reno, Nevada, January 13-16, 1986, General Technical Report. INT-215 (1987).

14. T. L. Smiley and P. J. Mehringer, Jr., Report to National Science Foundation for research supported by NSF Grant GB-8646, Post-pluvial history of the spring-fed salt marshes of the Amargosa drainage, pp. 35 (no date).

15. P. J. Mehringer, Jr. and J. C. Sheppard, Holocene history of Little Lake, Mojave Desert. California. pp. 153-176, in E. L. Davis (ed.). The Ancient Californians: Rancholabrean Hunters of the Mojave Lakes Country, .Vatural History Museum of Los Angeles County, Science Series 29, Los Angeles (1978).

16. P. E. Wigand. Diamond Pond, Harney County, Oregon: Vegetation history and water table in the eastern Oregon desert, Great Basin Vaturalist 47(3):427-458 (1987).

17. E. Blinman. P. J. Mehringer, Jr. and J. C. Sheppard. Pollen influx and tephra, pp. 393-425. in P. D. Sheets and D. K. Grayson (eds.), Volcanic activity and Human Ecology, Academic Press, New York (1979). 
is. C.M. Aikens. . irchaeology af oregon. L'S. Department of the Interior. Bureau of Land Management. pp. 302 (1993).

19. P. E. Wigand. and C. L. Nowak. Chapter 3 : Climate/Climate Indicators. Dynamics of northwest Nevada plant communities during the last 30.000 years. pp. 40-62. in Hall. Jr.. C. A.. V. Doyle-Jones and B. Widawski (eds.). The Historv of Water: Eustern Sierra Vevada, Owens Vallev. White-Invo Mountains, White Mountain Research Station Symposium Volume t. (1992).

20. P. E. Wigand. Chapter 2: Vegetation History, pp.15-48. in S.D. Livingston and F.L. Nials (eds.), Archaeological and Paleoenvironmental Investigations in the Ash Meadows National Wildlife Refuge, Nye County, Nevada. Quaternary Sciences Center, Technical report No. 70, (1990).

21. V. C. LaMarche, Paleoclimatic inferences from long tree-ring records. Science 183(4129): 1043-1048 (1974).

22. P. J. Mehringer. Jr. and C. W. Ferguson. Pluvial occurrence of Bristlecone Pine (Pinus aristata) in a Mojave Desert mountain range, Journal of the Arizona Academy of Science 5(4):284-292 (1969).

23. H. Craig, The geochemistry of stable carbon isotopes. Geochim. Cosmochem. Acta 3:5392 (1953).

24. H. Craig, Carbon-13 in plants and the relationship between carbon- 13 and carbon14 variations in nature. Journal of Geology 62:115-149 (1954).

25. R. Park and S. Epstein. Carbon isotope fractionation during photosynthesis. Geochim. Cosmochim. Acta 21:110-126 (1960).

26. R. Park and S. Epstein. Metabolic fractionation of $\mathrm{C}^{13}$ and $\mathrm{C}^{12}$ in plants. Plant Phvsiology 36:133-138 (1961).

27. H. P. Kortschak. C. A. Hartt and G. O. Burr. Carbon dioxide fixation in sugar cane leaves. Plan Phisioiogy 40:209-213(1965).

-8. i1. D. Ifatch and C. R. Slack. The $C_{4}$ carboxyic acid pathway of photosynthesis. pp. 35-106. in L. Reinhold and Y. Liwschitz (eds.). Progress in Phrtochemistry, WileyInterscience. New York (1970).

29. G. D. Farquhar. M. H. O'Leary and J. A. Berry. On the relationship between carbon isotope discrimination and the intercellular carbon dioxide concentration in leaves, Australian Journal of Plant Physiology 9:121-137 (1982).

30. G. D. Farquhar. K. T. Hubick, A. G. Condon and R. A. Richards. Chapter 2: Carbon isotope fractionation and plant water-use efficiency, pp. 21-40. in Rundel. P. W., J. R. Ehleringer and K. A. Nagy (eds.), Volume 68. Stable Isotopes in Ecological Research, in W.D. Billings, F. Golley, O. L. Lange, J. S. Olson and H. Remmert (series eds.), Ecological Studies: Analvsis and Synthesis, Springer-Verlag, New York (1988).

31. C. T. Garten and G. E. Taylor, Jr., Foliar $\delta^{13} \mathrm{C}$ within a temperate deciduous forest: spatial, temporal, and species sources of variation, Oecologia 90:1-7 (1992).

32. J. R. Ehleringer, C. B. Field. Z. Lin and C. $Y$. Kuo. Leaf carbon isotope and mineral composition in subtropical plants along an irradiance cline. Oecologia 70:520-526 (1986).

33. J. R. Ehleringer. Z. Lin. C. B. Field, G. C. Sun. C. Y. Kuo. Leaf carbon isotope ratios of plants from a subtopical monsoon forest, Oecologia 72:109-114 (1987).

34. K. Winter. J. A. M. Holtum. G. E. Edwards and M. H. O'Leary, Effect of low relative humidity on $\delta^{13} \mathrm{C}$ value in two $\mathrm{C}_{3}$ grasses an in Panicum milioides, a $\mathrm{C}_{3}-\mathrm{C}_{4}$ intermediate species. Journal of Experimental Botany 33:88-91 (1982). 
G. D. Farquhar. .1. H. O'Leary and J.A. i3erry. On the reiationsinip between carbon isotope discrimination and the intercellular carbon dioxide concentration in leaves. - ilustralian Journal of Plant Physiology 9:121-137 (1982).

36. R. J. Francey, R. M. Gifford. T. D. Sharkey and $\mathrm{B}$. Weir. Physiological influences on carbon isotope discrimination in huron pine (Lagarostrobos franklinii). Oecologia 44:241-247 (1985).

37 L. S. L. Sternberg, S. S. Mulkey and S. J. Wright, Ecological interpretation of leaf carbon isotope ratios: influence of respired carbon dioxide. Ecology 70:1317-1324 (1989a).

38. L. S. L. Sternberg, S. S. Mulkey and S. J. Wright, Oxygen isotope ratio stratification in a tropical moist forest, Oecologia 81:5156 (1989b).

39. C. Ducatti. E. Salati and D. Martins. Measurement of the natural variation of ${ }^{13} \mathrm{C}:{ }^{12} \mathrm{C}$ ratio in leaves at Reserva Ducke Forest, central Amazonia. Forest Ecology and Management 38:201-210 (1991).

40. M. D. Morecroft and F. I. Woodward, Experimental investigations on the environmental determination of $\delta^{13} \mathrm{C}$ at different altitudes. Journal of Experiment Botany 41(231): 1303-1308 (1990).

41. E. Madsen. Effect of $\mathrm{CO}^{2}$-concentration on morphological. histological. cytological and physiological processes in tomato plants. Acta Agricultural Scand. 23:241-246 (1973).

42. J. W. O'Leary and G. N. Knecht, Elevated $\mathrm{CO}_{2}$ concentration increases stomata numbers in Phaseolus vulgaris leaves. Bot. Gaz. 142:438-441 (1981).

43. K. Imai. D. F. Coleman and T. Yanagisawa. Elevated atmospheric partial pressure of carbon dioxide and dry matter production of Cassava (Manihot esculenta CRANTZ).
Jup. jour. Crop science $53: 479-485$ (1984).

4. I. I. Woodward. Stomatal numbers are sensitive to increases in $\mathrm{CO}_{2}$ from preindustrial levels. Yature $327: 617-618$ (1987).

45. J. R. Ehleringer. Chapter 3: Carbon isotope ratios and physiological processes in aridland plants. pp. 41-54. in P. W. Rundel, J. R. Ehleringer and K. A. Nagy (eds.), Volume 68. Stable Isotopes in Ecological Research. in W. D. Billings, F. Golley, O. L. Lange, J. S. Olson and H. Remmert (series eds.), Ecological Studies: Analysis and Synthesis, Springer-Verlag, New York (1988).

46. H. C. Fritts. Tree Rings and Climate, Academic Press, New York, 567 pp. (1976).

Figure Captions:

Figure 1. Juniper pollen values from the Lower Pahranagat Lake record for the last 2,000 years indicating periods of winter dominated rainfall.

Figure 2. Juniper to grass pollen index from Diamond Pond, south-central Oregon for the last 6,000 years. Periods of winter dominated rainfall are clear between 2.000 and 4,000 b.p., c. 1,000 b.p. and about 300 b.p.

Figure 3. Plot combining number of dated woodrat midden strata per 1000 year period from the Great Basin with values for the relative proportion of pine and juniper pollen to saltbush pollen in records from the valleys of southern Nevada during the last 45.000 years.

Figure 4. Elevational plot of directly dated Limber Pine and White Fir macrofossils from ancient woodrat middens from a 200 -mile radius around Yucca Mountain (our own and previously published data). Pluvial Lake Lahontan curve plotted at bottom of diagram is after Benson et al 1990. 
Figure 3. Plot of $013 \mathrm{C}$ values on piant materiais rom strata or a single woodrat den in the Virginia Mountains of NW Nevada. $013 \mathrm{C}$ values of plant materiais are normally considered to be a measure of plant water use efificiency. However. a polynomial curve tit and its similarity to late Quaternary temperature variations suggest that temperature may be a strong influence over the long-term.

Figure 6. When a best fit curve is plotted against the $\delta 13 \mathrm{C}$ values of materials obtained from woodrat midden strata around the Pluvial Lake Lahontan basin the result looks much as did that from the single nest from the Virginia Mountains (Figure 5). Therefore. long stable isotopic records from a single locality mirror the massed data from an entire region. Both reflect the longterm effect of temperature, whereas short-term outliers probably reflect increased water use efficiency as a result of droughts.

Figure7. The long-term regional temperature pattern is also revealed in a comparison in the figure above of our $\delta 13 \mathrm{C}$ values from the Virginia Mountain midden in NW Nevada (squares with the solid line) and the values obtained by Siegel from North Snake Range middens in eastern Nevada (triangles with the dashed line).

Figure 8. This pattern also appears when $\delta 13 \mathrm{C}$ values from northern Nevada are compared with those from southern Nevada.

Figure 9. Comparison of the $\delta^{13} \mathrm{C}$ values for the last 4,000 years in the Yucca Mountain area with the Conifer to Saltbush Pollen ration from Lower Pahranagat Lake. It is clear that periods of increased effective, winter-dominated rainfall periods correspond to periods of increased $\delta^{13} \mathrm{C}$ enrichment.

Figure 10. Comparison of (from bottom to top) ratio of large to smail charcoal form the Diamond Pond record. ration or juniper to grass and $\delta{ }^{13} \mathrm{C}$ values trom the northern Great Basin.

\section{SECTION 2:}

\section{ACCOMPLISHMENTS OF PALEOFAUNAL STUDIES 1993-1994 \\ Stephanie Livingston. Principal Investigator}

\section{Project Goals}

The goal of this study is to construct a late Quaternary history of Great Basin vertebrates, particularly the endothermic taxa (birds and mammals). The vertebrate history will provide empirical evidence of past environmental and climatic conditions within the Great Basin as it is recorded by the animals. Taxonomic composition of archaeological and paleontological faunas from various areas within the the Great Basin and morphological change within individual mammalian taxa at specific localities are being investigated to monitor faunal response to changing environmental conditions. Data are being obtained from published records, modern museum specimens, and raptor pellets to provide a modern control to which the paleofaunal data can be compared. This study will provide an independent set of surrogate data for use in building a model of past conditions and assessing the effects of past climate change on various aspects of the environment.

Tasks and Progress on each:

1. Data collection from existing paleontological and archaeological vertebrate collections.

Archaeological and paleontological collections for which identifications have been completed and analysis is in report writing phase:

Pintwater Cave

Pahrump Valley Rockshelters

Archaeological and paleontological collections for which analysis is in progress: 
Floating island Cave all vertebrates recovered

Homestead Cave avian fauna

Handprint Cave

DeLong Mammoth Locality

z. Field work conducted from which collections for analysis will be obtained.

Reconnaisance surveys were conducted in the Las Vegas Valley, Pahrump Valley. Eureka Dunes area. Fish Lake Valley, and surrounding areas. Several localities are being evaluated and considered for further investigations. Two smail rockshelters were tested in the Pahrump Valley that apparently have very short, late Holocene records. Two rockshelters were located in the Eureka Valley that are being considered for testing.

3. Data collection from existing museum collections for modern standards.

Mensural data collected from Neotoma and Thomomys specimens in the collections at the Nevada State Museum and Historical Society

4. Dating and other special analyses.

A core was taken in the DeLong locality for paleomagnetic, ostracode and radiocarbon analysis. The dates and analyses for that core have been run and are in the report writing stage. 5. Integrative analysis.

To facilitate analysis and interpretation of the variety and spatial distribution of the different kinds of data that are being collected. the faunal database is being compiled in a GIS-compatible format. It will use the USGS DEM data as a base. and provide a Great Basin-wide history of bird and mammal faunal data through the late Quaternary.

Suggestion for further funding request:

We should consider requesting a post-doctorate position be funded for Craig Young to continue his work on the GIS presentation of the data. It could include integrating the geomorphology and paleobotany data and results into the database that is being initiated with the faunai data. The resuitant database would allow all researchers in the project access to information from various aspects of the project. from which they could assess the implications of their data for the big, integrative picture of the results of all data collected.

\section{SECTION 3:}

\section{GEOMORPHOLOGY STUDIES IN THE} GREAT BASIN

Nicholas Lancaster, Principal Investigator

Project Goals

The objective of the geomorphology component of the paieoenvironmental program is to document the response of surficial processes and landforms to climatic changes in the region as determined by studies of packrat middens, pollen, and faunal distributions. This project focuses on: (1) stratigraphic relations between lake deposits and aeolian and fluvial sediments and landforms; (2) cut and fill sequences in river channel and floodplain deposits, (3) identification of periods of dune mobility and stability; (4) documentation of periods of alluvial fan deposition and erosion; and (5) correlation of periods of fluvial and aeolian activity with changes in lake level as revealed by shoreline features such as strandlines and beach ridges. Numerical and relative dating techniques will be used to develop a chronology of events and to facilitate correlation with proxy paleoclimatic data.

These goals will be achieved via concentration on a series of geographical areas and sub tasks. This report summarizes progress on the various sub tasks to date and highlights some of our major accomplishments in the past year. 
ALLLVIAL FAN RESPONSE TO CLIMATIC

CHANGE. BUENA VISTA

VALLEY.CENTRAL NEVADA

Jerry R. Miller. Jennifer Husek and John B. Ritter.

Introduction

Buena Vista valley, located in central Nevada approximately $20 \mathrm{~km}$ southwest of Winnemucca. is the smallest of seven sub basins of Pluvial Lake Lahontan. Currently, the valley is characterized by a large playa surrounded by alluvial fan deposits which head in the Humbolt and East Humbolt ranges. The alluvial fans in the vicinity of the playa have been affected by shoreline processes associated with Pluvial Lake Lahontan. Farther north, the distal fan areas are located above the high lake level stands. Beginning in April, 1993. a study was initiated with the primary objective of determining the geomorphic response of alluvial fan systems in the valley to climatic shifts that have characterized this region during the past 25.000 years. Specifically, we are interested in determining the timing of fan building events and whether these depositional episodes are controlled by variations in runoff and sediment yield in headwater areas or by base level changes associated with water level fluctuations of Pluvial Lake Lahontan. We are also interested in assessing the role of tectonic activity in alluvial fan deposition and morphology. As will be discussed in more detail below. we hypothesized that such data would have important implications to the timing, spatial distribution. and magnitude of precipitation shifts during the late Pleistocene and Holocene.

To date, the geomorphic and stratigraphic nature of eight alluvial fans in the basin have been documented in detail and numerous other fans have been examined during field reconnaissance. Although the work is still ongoing. a number of preliminary results and conclusions have been developed from the initial field studies. They are summarized below.
Resuits and Discussion

The alluviai tans in Buena Vista valley are segmented. That is. they are composed of several depositional units. deposited at different times. and which are spatially distributed on the fan complex at distinct locations thereby giving the fan. in longitudinal protile. an appearance that it is composed of several straight-line segments. These stratigrapnic units were delineated in the field on the basis of topographic and stratigraphic position, surface micro-relief, desert varnish thickness on clasts, and degree of material weathering. Each of the eight alluvial fans examined exhibit five units named here from oldest to youngest. Alluvial Fan Unit 1 (Qf1),Alluvial Fan Unit 2 (Qf2), Alluvial Fan Unit 3 (Qf3), Alluvial Fan Unit 4 (Qf4), and Alluvial Fan Unit 5 (Qf5).

The absolute timing of unit deposition has yet to be determined. However, tephra has been collected from units Qf2 and Qf3 and is now being analyzed to determine the approximate timing of these two depositional episodes. A relative chronology related to high stands of Pluvial Lake Lahontan has. however, been tentatively established on the basis of observed stratigraphic relationships.

In summary, Qf2 is inset into Qf1 and is the dominant geomorphic surface of which these alluvial fans are composed. Examination of trench walls shows that Qf2 pre-dates the highest lake stands observed in this valley. By contrast, Qf3 post-dates the shoreline features. In most locations. water and sediment associated with Qf3 deposition was ponded upfan of constructional beach ridges: a process that subsequently led to ridge breaching. It is unclear at this time if Qf3 was deposited during lake level decline or well after significant lake stands in Buena Vista valley existed. Units Qf4 and Qf5 represent moderm depositional units that are located along entrenched fan channels in apex- and medial-fan areas and as secondary fans in distal fan areas. 
There are severai signiticant conciusions that can be drawn from the stratigraphic relationsnips described above. The stratigraphic data suggest that fans within the Buena Vista valley exhibited nearly synchronous deposition. For exampie. Qf2 is of similar age on each of the alluvial tans examined. as is Qf3. This observation appears true whether the fans were affected by Pluvial Lake Lahontan (as in the southern part of the valley) or not (as is the case in the northern portion of the valley). This suggests that such regional fan building episodes were driven by changes in climate. This is supported by the fact that local faulting (geomorphic surface offset) of Qf1 and Qf2 deposits on several of the fans did not lead to the development of significant fan stratigraphic units. Given that climate is the primary driven force for alluvial fan deposition. determining the absolute age of each of the fan units may provide important clues as to the timing of major climatic shifts in this region. The geomorphic data will therefore act as another form of climatic proxy data that can be used to decipher the timing of change in effective moisture in this area.

There is no evidence that fan deposition is initiated by changes in base level related to lake stage fluctuations. Alluvial fan surfaces "graded" to ancestral shorelines do not exist. In fact. fan units that are both temporally and spatially correlative with any of the identified shoreline features are lacking. This reinforces the conclusion that the primary driving force of alluvial fan deposition in this area is climate, and the responses are predominantly controlled by changes in runoff and sediment yield within headwater areas.

One surprising observation is that geomorphic surfaces temporaily correlative to lake level rise are not identified on any of the fans in this area. It has often been suggested that lake level rise is associated with local runoff from tributaries surrounding the basin. It would seem highly improbable for a significant quantity of water and sediment to enter Buena Vista Valley without creating some geomorphic fan evidence of inflow. Thus. we have hypothesized that water may have entered Buena Vista valley from the Carson Sink by overtlowing the sill which separates the two sub basins.

Important paleoclimatic/paleoecological questions have been derived from these preliminary results including (1) what were the sources of water for Pluvial Lake Lahontan; (2) why did significant decreases in base level did not influence the alluvial fan systems; (3) what was the influence of vegetation on mediating runoff and sediment yield with the drainage basins; and (4) what was the time of the depositional episodes and lake level fluctuations. With regards to the last question. data has been sought to construct a lake level fluctuation curve for the Buena Vista valley area. To date, ostracode shells have been found and collected from 7 constructional shoreline features including the highest beach ridge and will be dated using $\mathrm{AMS} /{ }^{14} \mathrm{C}$ techniques. In addition, the elevation of each of the shorelines has been determined, either though normal survey techniques (using an electronic distance meter) or though the uses of a Global Positioning System (GPS). The combined data will allow for a general lake level fluctuation curve to be developed and compared to previous studies of Pluvial Lake Lahontan. Three dates have already been obtained from beach ridges located on the Klondike Canyon alluvial Fan. These dates. interpreted on their own, suggest that lake levels may have been lower than generaily supposed between 12,390 and 14,540 yr. BP.

SEDIMENTOLOGY, STRATIGRAPHY, AND
CHRONOLOGY OF LACUSTRINE
DEPOSITION IN THE FERNLEY BASIN,
WEST-CENTRAL NEVADA.
Kurt Cupp and Nicholas Lancaster

SEDIMENTOLOGY, STRATIGRAPHY, AND CHRONOLOGY OF LACUSTRINE DEPOSITION IN THE FERNLEY BASIN, Kurt Cupp and Nicholas Lancaster 
introduction

Pluvial Lake Lahontan consisted of seven sub basins that only coaiesced into one lake at the very highest levels. For much of the late Pleistocene and Holocene these basins responded separately (and possibly in a unique manner, to climate change in the region. A full understanding of the history of this major Pleistocene pluvial lake can only be developed by detailed studies of the deposits and landforms of each of the sub basins and by subsequent correlation between well-dated events in each basin.

The Fernley sub basin lies between the Truckee River - Pyramid Lake basin and the much larger Carson Sink basin. Lake leveis in the basin are controlled by the elevation of three sills: Darwin Pass (elevation $1238 \mathrm{~m}$ ) which separates it from the Carson Sink; Ferniey Sill (1265 m) which separates the basin from the Truckee -Pyramid Lake basin.:and an un-named sill ( $1300 \mathrm{~m}$ ) to the NE between the Fernley and Humbolt basins.

Results

Fieldwork has involved detailed geologic mapping of late Quaternary sediments and lacustrine features combined with precise control of elevations (using an electronic distance meter) and descriptions of sediments for each of the major sedimentary units. Materials suitable for ${ }^{i 4} \mathrm{C}$ dating have been identitied and samples of tephra have been collected. These will provide age-control for some of the map units.

Three high level erosional shorelines have been identified in the basin:

1) 1332 to $1334 \mathrm{~m}$ (very weak
development)
2) $1331-1332 \mathrm{~m}$ (very strong lithoid tufa
development and bench)
3) 1320 - $1322 \mathrm{~m}$ (strong erosional bench)
Horizontally-bedded lacustrine deposits
- have been identified at many localities in the

Ferniey Basin at elevations of 1245 to $1250 \mathrm{~m}$. 1273 10 $1276 \mathrm{~m}$. and 1283 to $1292 \mathrm{~m}$. Some tectonic deformation $(1$ to $2 \mathrm{~m}$ ) of shorelines is evident in this basin.

\section{Discussion}

Topograpny and lacustrine deposit and shoreline elevations suggest that the Fernley Basin has a complex three-stage lake history. At lake levels below $1238 \mathrm{~m}$ the basin has a unique history. Between $1238 \mathrm{~m}$ and $1265 \mathrm{~m}$ the basin was connected to the Carson Sink via the Darwin Pass. At lake levels above $1265 \mathrm{~m}$, the basin was connected to the Pyramid Lake basin. The strong development of lacustrine deposits at elevations of 1245 to $1250 \mathrm{~m}$ suggests a long-lived lake fed by inflow from the Carson and Humbolt Rivers. This has important implications for the paleohydrology of Lake Lahontan.

We plan to take sediment cores from the basin to more fully document the history of lakes at levels below $1238 \mathrm{~m}$, and develop a numerically-dated chronology for lacustrine episodes.

TREE-RINGS, LAKE CHRONOLOGIES, ALLUVIAL SEQUENCES AND CLIMATE: IMPLICATIONS FOR GREAT BASIN PALEOENVIRONMENTAL STUDIES

Fred L. Nials and Donald A. Graybill (deceased), University of Arizona. Laboratory of Tree-Ring Research [sub contract]

\section{Introduction}

Bristlecone pine (Pinus aristata) tree-ring chronologies from multiple climate-sensitive localities across the central and southern Sierra Nevada. southern Great Basin. and Four Corners area provide continuous records of annual growth over periods of more than 5.000 years. Analysis of data from numerous localities and their comparison with other paleoclimatic proxy data will allow resolution of questions regarding 
spatiai and temporal variability in Holocene paieocimate across the southern Great Basin.

Resuits

Two of these chronologies. Methuselah Walk and Indian Gardens. have been analyzed in detail. Preliminary measurements and comparison with other paleoenvironmental data indicate that these chronologies provide sensitive and precisely dated records of climate variability, allowing measurement of the duration and frequency of occurrence of events of specific magnitudes.

The Methuselah Walk chronology is from the White Mountains of southern Califomia. and is the longest known tree-ring chronology in existence. having a duration of more than 8.600 years. Several aspects of this chronology are notable. Lengthy periods of drought are common. Some of the more conspicuous include droughts of 650 years (ca. 7,250-6,600 BP), 250 years (ca. 4.650-4.400 BP), 300 years (ca. 3.700-3.400 BP), and 600 years (ca. 1,100-500 BP). Dry periods are interspersed with periods of relatively "wetter" conditions, with two of the "wettest" occurring during a 400-year period between ca. 7,650-7,250 $\mathrm{BP}$, and another of similar duration between ca. $500 \mathrm{BP}$ and $100 \mathrm{BP}$.

Comparison of preliminary analyses with other paleoenvironmental data reveal marked co-variance. For example, data from Pahranagat Lake. Nevada (developed by Wigand and co-workers in the paleobotanic studies part of this project). reveal that in the most recent 4.000 years significant deviations in frequencies of grass. aquatics, sage, pinyon, juniper, chenopods, and Ambrosia pollen occurring at ca. $1.000 \mathrm{BP}$ and 2.500 BP have striking temporal correspondence to the Methuselah Walk chronology. The tree-ring record parallels other types of paleoenvironmental data. and has the advantage of being precisely datable. In addition, the use of long-term dendroclimatic reconstructions in combination with high frequency pollen spectra covering the same time period offers a protocol for quantitatively measuring the response of pollen spectra to variations in climate.

Comparison between the Indian Garden Locailty in the White Pine Range of north-central Vevada and the Methuseiah Walk record reveals severai differences. This drought-sensitive location also shows variable climate during the ca. 5.200 years of the tree-ring record. but amplitudes of variation are generally smaller than in the Methuselah Walk chronology. Most major dry periods do not correspond in time. Droughts in the Indian Garden area are of somewhat shorter duration, and appear to be of reduced severity. Some of the more significant appear to have occurred between ca.4.500-4,100 BP, 3,300-2,950 BP, 2,100-1,800 BP. 1,600-1,400 BP, 1,200-950 $\mathrm{BP}$, and 550-150 BP.

\section{Discussion}

A major climate shift appears to have occurred in the Great Basin beginning ca. 1,100 BP. At that point in time the two signals diverge markedly in trend, with the southern Sierra becoming much drier and central Nevada becoming wetter. Conditions are reversed at about 500 BP and continue in opposition until the present. Pollen frequencies at Pahranagat Lake and Diamond Pond $^{2}$ (south-central Oregon) deviate at about 1,100-1,000 BP.

Some perturbations of climate appears to be reflected in the geomorphic record, for arroyo-cutting episodes began in numerous locations from northern Nevada to the Southwest at ca. 1,050-950 BP. Elsewhere in northern Nevada. archaeological evidence documents a period of erosion during the period 3,500-3,000 $\mathrm{BP}$, corresponding with one of the longer droughts in the Indian Garden record.

Alluvial and Lacustine Data

Stratigraphic data collected thus far during this study are clarifying some of the depositional 
history of the northern and centrai Great Basin. These ciarifications wiil aid in the determination of whether. when and how otten significant movements of the winter and summer westerly storm tracks have occurred.

Geological and dendrociimatologicai investigations have shown variations in climate and climate-driven geomorphic processes that are in concert with other types of paleoenvironmental data. Both climate and process have varied significantly during the late Pleistocene and Holocene. The temporally-sensitive tree-ring records show that major shifts from "wetter" to "drier" conditions and back may occur within a decade or less. In addition. climatic conditions and dominant geomorphic processes that have prevailed during the last 150 years are not representative of the majority of Holocene climate in the state of Nevada. The temporal precision of dendroclimatic records may facilitate and increase the accuracy of interpretation of other types of paleoenvironmental evidence.

Field activities to date have been concentrated in areas of the northern and central Great Basin along a north south transect that will enable tracking and timing of storm track movements. A general climatic framework has been formulated that can be refined to used in conjunction with paleobotanical and paleozoological data to refine our estimates of timing and magnitudes of late Quatemary periods of increaased effective precipitation. We emphasize that these are only preliminary estimates of the climate flux whose timings and magnitudes will be modified as more information becomes available.

25,000 b.p.. Lake Lahontan dry, extensive alluvial deposition on basin floor.

24,000 b.p. Lake Lahontan begins to fill, ostracode analysis shows lake levels to be relatively low and variable in the upper Black
Rock basin until ca. 18.000 b.p. (interpolated from radiocaroon dates on cores 1 .

22.800 b.p. Trego Ash deposited. defines lake level at that time.

18,000 b.p. Lake level rises.

18,000 to 17,000 b.p. Major influx of fresh water into lake. Lake rises to inferred maximum late Pleistocene level (interpolated from radiocarbon dates on cores..

15,500 b.p. Major lowering of lake levels (eventually to below $1215 \mathrm{~m}$; dating based upon previously published radiocarbon date).

$15,334+/-117$ b.p. Youngest lacustrine sediments that have been identified in the Black Rock basin at an elevation greater than $1210 \mathrm{~m}$. Shortly thereafter lake clays are incised by streams at levels above approximately $1210 \mathrm{~m}$ (sediments dated by both radiocarbon and paleomagnetic techniques). Incision of fans and alluvial valleys adjacent to pluvial lake basins may begin at this time, but this event is still poorly dated.

14,500 b.p. (?) Lake level again rises slightly, but lacutrine sediments or geomorphic features relating to this event above $1210 \mathrm{~m}$ have not been identified $(1335 \mathrm{~m}$ is highest Wisconsin lake stand). Alluvium is deposited above this elevation in the Black Rock basin.

$\sim \mathbf{1 3 , 5 0 0}$ b.p. Lake again begins to dry (previous investigations of others, no evidence in the Black Rock basin). Prior to this prominent soils have been developing on fans and other suitable exposed surfaces above lake level. Incision of lake floor begins. continues on fans and in alluvial valley, removes much of alluvium in most valleys.

11,500 b.p. Smoke Creek. Black Rock Desert, 
and Desert Valley sub-basins are essentiaily dry: peopie occupy some iucations in casin lloors. Most basin floor topography lexcept aeolian Catures) had essentiaily attained its present contiguration by this time.

11,500 7,200 b.p. Slope processes deposit coarse deposits at base of slopes in most locations across northern Nevada. character of deposits suggests cooler climate: relatively little direct evidence of extensive loessal deposition or dune formation except in direct proximity to exposed basin floors. A strong soil forms in most locations throughout northern Nevada at this time. Tree-ring records one of the wettest periods in the last 8.600 years from $7.650 \mathrm{BP}-7.250 \mathrm{BP}$.

11,000-10,500 b.p. Climate becomes wetter across northern Nevada. small lakes may be present in some basins. Perennial streams flowed in now-dry drainages in numerous areas in northeastern Nevada.

7,250 b.p. Pan-northern Nevada period of erosion incises channels in valley floors, erodes late Pleistocene/Early Holocene soil and slope deposits. Increased evidence of loessal deposition just prior to erosion. Tree-ring records indicate 650-year drought begins in White Mountains. CA area at approximately 7,250 b.p. Mean precipitation is low, but variability is high during this drought.

7,000 b.p. Mazama Ash deposited across northern Nevada.

7,000-3,400 b.p. Strong influx of loessal sediments across northern Nevada. Much of this material is eroded and re-deposited in deep alluvial fills. Slope and alluvial processes diverge markedly from pre-7.000 b.p. patterns. Evidence in many locations for increased frequency of flood events. Dendroclimatological records indicate hat in central and southern Nevada this period is punctuated by maior long-iasting droughts at $-7.250-6.600$ b.p. $(650$ years $) .4 .650-4.400$ b.p. 1250 vears- very low precipitation. very low variabilityı. $-3.700-3.400$ b.p. 1300 years- very low precipitation. very low variability).

$\sim 3,000$ b.p. Arroyo-cutting in some localities. followed byaliuviation that heals arroyo incisions.

$\sim$ 1,500 b.p. Arroyo-cutting in some areas.

1,100-500 b.p. Major drought characterized by low mean precipitation but high variability occurs throughout most of Nevada. Major arroyo incision in most of state is roughly contemporaneous with similar events throughout Southwest.

500-100 b.p. Unusually wet period in southern Nevada coincided with much of early Euroamerican settlement of area.

\section{SECTION 4:}

\section{STABLE ISOTOPIC VALIDATION STUDIES: FOSSIL SNAILS}

Saxon Sharpe. Joe Whelan and Rick Forester

As part of the QA validation of the conclusions drawn from ancient woodrat midden stable isotope studies. analyses of stable isotopes from late Quaternary snails are being conducted. Because $\delta{ }^{18} \mathrm{O}$ may be an accurate indicator of past temperatures. studies are being undertaken with fossil and modern analogue snails to determine if additional evidence can be accumulated regarding the history of past lowered Pleistocene temperature. Lowered temperature is a major factor in increasing effective precipitation. Because stable isotopic studies of ancient woodrat midden s seem to indicate that many of the more mesic periods of the Pleistocene were. in part. the 
¿sult of wwered mean annual ismerature sabic

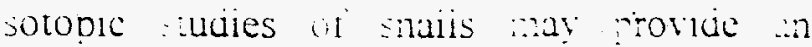
independent measure of these decreases. Is a result if contirming information can be obtained :evarding late Quaternary imperature instory hrougin staole isotopic suaies il snais. ine relative intluences of temperature and actual increased rainfall can be evaluated with regards to sround water recharge.

Thus far. field collection. processing. sorting, identification, and isotopic analyses of molluscs initiated in September 1993 resulted in 1 paper and 2 presentations (see citations). Preliminary results indicate that the terrestrial moiluscs in southern Nevada are recording lighter isotopic values of $\delta{ }^{18} \mathrm{O}$ with increasing elevation. This indicates that the ${ }^{18} \mathrm{O}$ values from modern shells provide a record proportional to the ${ }^{18} \mathrm{O}$ values from precipitation. Because land snail shell growth is limited to summer. the shell ${ }^{18} \mathrm{O}$ value orfers a way to compare past source areas of summer rain with those of today.

Differences in the $\delta{ }^{18} \mathrm{O}$ values between late-glacial and modern shells were also found. This suggests that the depleted values in the fossil material were recording isotopically lighter winter water discharged from springs or that late-glacial molluscs were recorcing summer climates that were wetter and cooler than modern. If the latter is the case. these data could indicate a significant difference in atmospheric circulation between late-glacial and modern patterns. The late-glaciai summertime principal precipitation source could have been continental or maritime polar air masses. not the current Gulf component we experience today. Collection and analyses of terrestrial molluscs from varying geographical and elevational sites are ongoing.

Aquatic molluses were collected in coniunction with the L.S.G.S. Lakes. Climate and Ostracodes Project from localities across an effective precipitation gradient (North Dakota. Montana. Wyoming). Processing. sorting. ientitication. and analyses or this materiai are in process.

Citations

1) Molluses as Climate Indicators: Preliminary stable isotope und Community Anaiysis. In "IHLRWM Proc.. ASCE and ANS, 5th International Conference". Las Vegas, Vevada. With J.F. Wheian. R.M. Forester. and T. McConnaughey.

2) Quaternary Paleoclimatology from Community and Stable Isotope Studies of Terrestrial Snails. In American Quatemary Association Programs and Abstracts, 13th Biennial Meeting, June 1994. Poster With J.F. Whelan. R. M. Forester. and M. M. Rose.

3) Paleociimatic and Biogeographic Inferences from Stable Isotope And Community Analysis of Great Basin Landsnails. In The Western Society of Malacologists Program and Abstracts 27th Annual Meeting. June 1994. With J.F. Whelan. R. M. Forester. M. M. Rose and R. J. Moscati.

\section{SECTION 5:}

\section{LATE PLEISTOCENE AND HOLOCENE EOLIAN . ACTIVITY IN THE MOJAVE DESERT}

Nicholas Lancaster. Ann G. Wintle, and Michèle Clarke (Institute of Earth Studies. University of Wales. Aberystwyth [sub contract].

\section{Introduction}

A major problem in determining the response of arid-region eolian deposits and landforms to climate change has been the difficulty of providing an absolutely-dated chronology of events. In conjunction with conventional stratigraphic and geomorphic studies. luminescence dating techniques (TL, OSL. and IRSL) provide the means to develop a numerical chronology of periods of eolian activity 
nc cune rormation that can de correlated wh ther sources or proxy paicocitmatic data.

Results

Stratigraphic and luminescence dating studies have been conducted at numerous sites in ihe sediment transport system that feeds Kelso Dunes. in central and eastern Mojave Desert of California. We have concentrated on this system because it displays close relations between input of sediment from fluvial and lacustrine sources and aeolian activity. The system appears to be sensitive to a range of possible climatic changes.

Infra-red stimulated luminescence (IRSL) techniques have been applied to aeolian sands associated with playa shorelines (East Cronese Basin) and dune ridges (West Cronese Basin). The Cronese Basins, located north of the Mojave River Wash in the eastern Mojave Desert, are fed by flow in the ephemeral Mojave River as a response to increased rainfall in the San Bernardino Mountains. Results from the West Cronese Basin show that dune ridges range in age from $155 \pm 90$ years to $1850 \pm 200$ years with the majority of dune stabilization occurring around 200 years ago. A sample taken from a one meter high yardang at the south side of the West Cronese Basin near the spillway. gave an age of $250 \pm 75$ showing that there has been significant erosion and transport of sand from the West Cronese Basin since that time.

Kelso Dunes covers an area of approximately $100 \mathrm{~km}^{2}$ at an elevation of 500 $900 \mathrm{~m}$ on the piedmont alluvial deposits of the Granite and Providence Mountains. It forms the depositional sink for a well-defined eolian sediment transport system that extends from the fan-delta of the Mojave River as it exits the Afton Canyon eastwards to the piedmont of the Providence Mountains. Luminescence dating of dune and sand sheet units provides minimum age estimates for some parts of the dune field. IRSL ages obtained so far indicate that there is a exponential increase in the age of dune and sand ineet units rom northwest to southeast. supporting the inypothesis that the dune field accumulated by stacking or shingling of successive generations of eolian units on the piedmont of the Providence and Granite Mountains. The oldest sands known are those which were deposited as sand sheets on alluvial fan surfaces as much as $5 \mathrm{~km}$ southeast of the present dune margins $16.830-17.300$ yr. ago. Dunes on the eastern margin of the dune field were accumulating $8,420-10,410$ years ago, but were stabilized in a period of cooler and wetter climates in the period around 3,900 yr. BP. Later periods of dune formation and/or reactivation occurred on the northern and western margins of the dune field around $1.500 \mathrm{yr}$. and $400-800 \mathrm{yr}$. ago.

It appears that Kelso Dunes is a very good example of a dune field that has developed in response to Quaternary climatic changes in the Mojave Desert. Sedimentary and geomorphic relations between the multiple areas of different dune morphology suggests that they have accumulated as a series of genetically independent dune fields during periods of increased sediment supply and became stabilized during wetter climatic episodes. Currently, the dune field is receiving no sediment from its primary source. Based on the experience of modern floods (e.g. January 1993), periods of increased sediment supply to the dune field imply more frequent flooding of the Mojave River through Afton Canyon.

Compilations of data from the eastern and central Mojave indicate two major regionally-extensive eolian depositional episodes in the past $40 \mathrm{ka}:$ (1) $30-20 \mathrm{ka}$. and (2) $15 \mathrm{ka}-7$ ka. Significant periods of Holocene eolian activity also occurred in the Mojave River - Kelso Dunes sediment transport system at around $4 \mathrm{ka}$. $2.3-1.4 \mathrm{ka} .0 .8-0.4 \mathrm{ka}$, and $0.2 \mathrm{ka}$. These data suggest that there was a major change in the eolian environment in the Mojave Desert during 
the eariy Holocene. Prior to this ime. sediment supply irom liuctuating piuviai lakes and more active fluvial systems was sufficient to promote the accumulation of large climbing and falling dunes. After the desiccation of the region in the latest Pleistocene and eariy Holocene. sediment supply declined dramatically so that later Holocene eolian activity was restricted to the reworking of major dune fields (e.g. Kelso) and to areas of active sediment supply (e.g. the Cronese Basin). We interpret this temporal and spatial pattern as an indication that sediment supply is the major control of eolian accumulation in this and probably other desert regions.

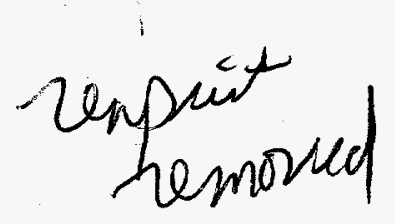




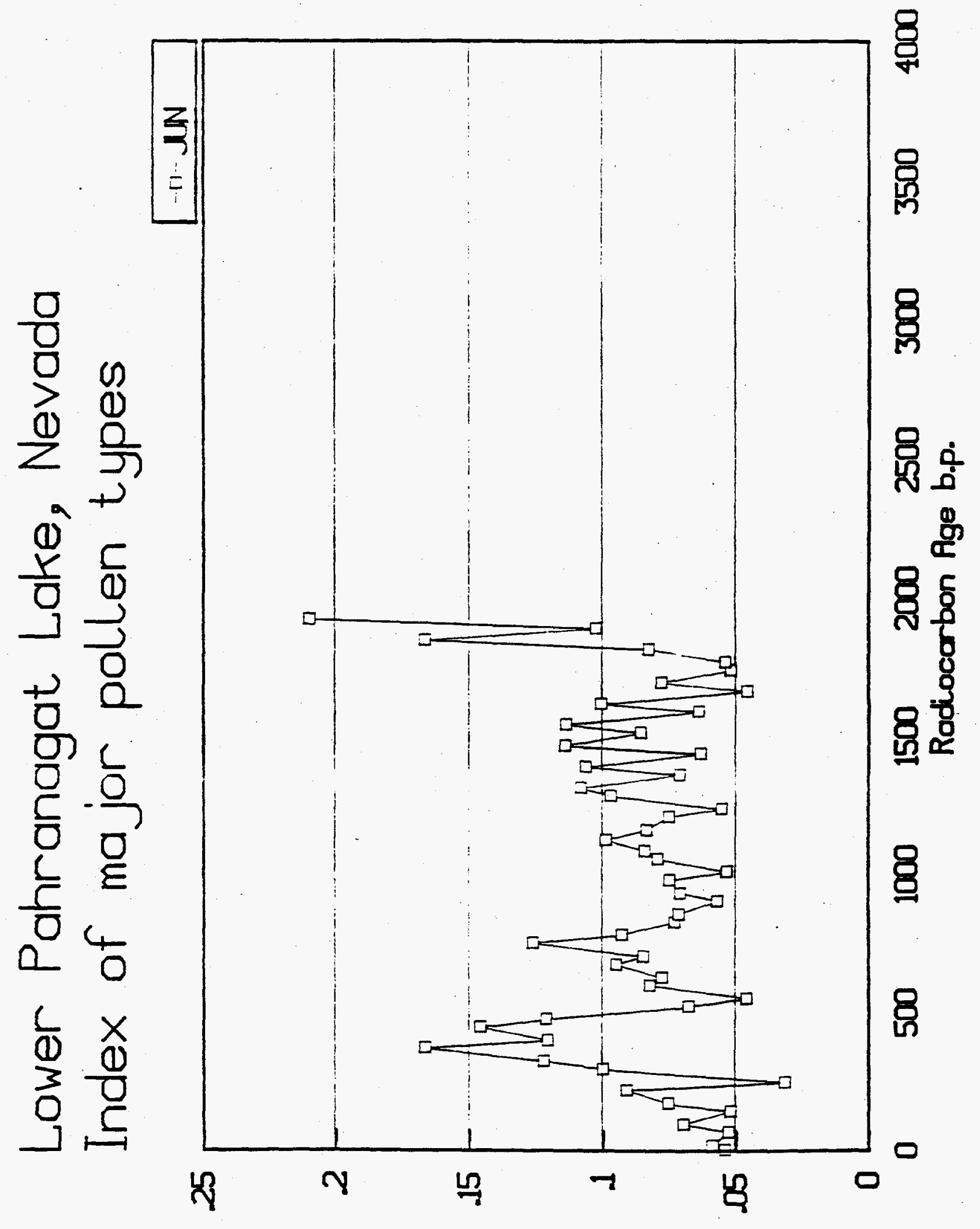




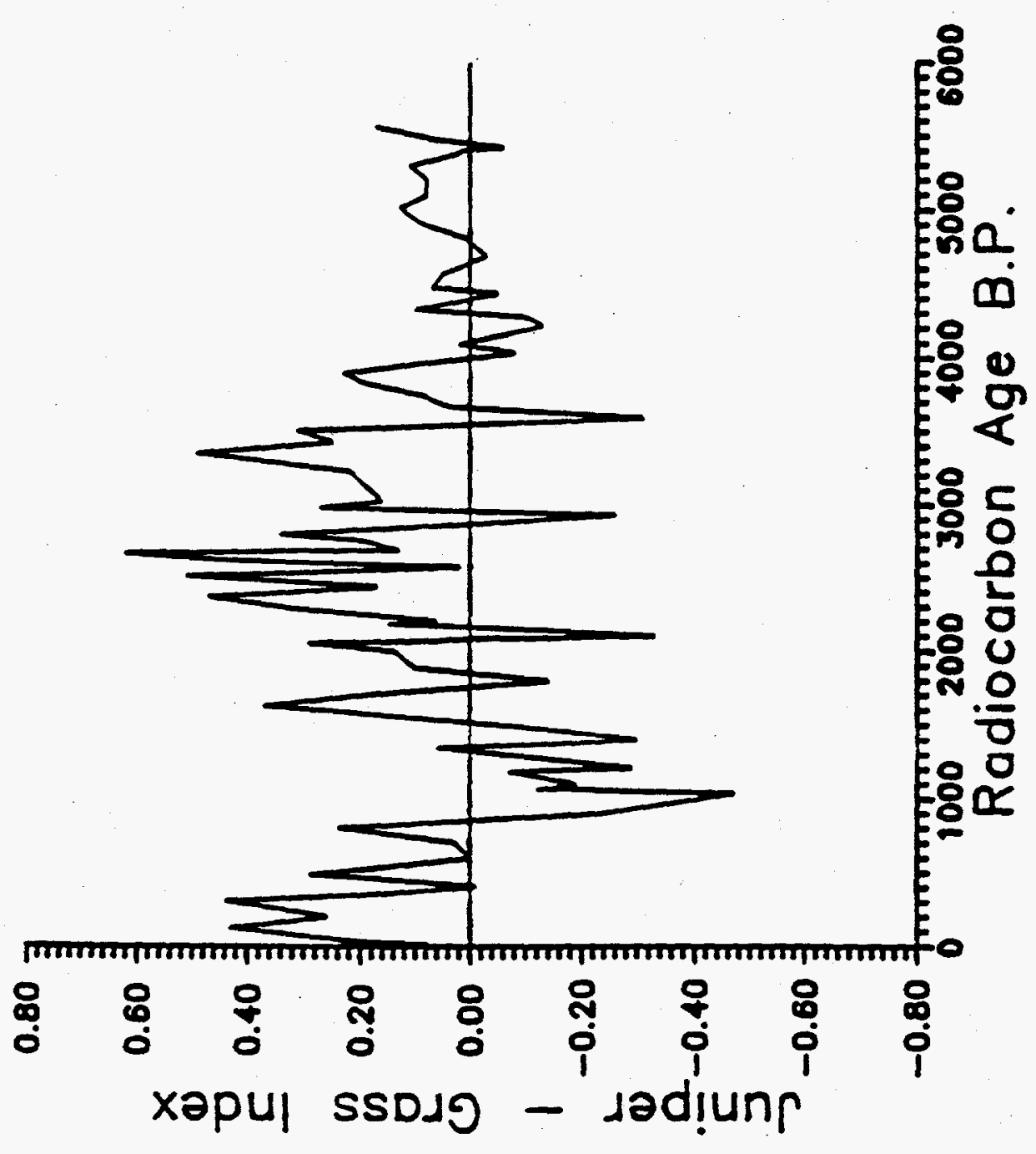




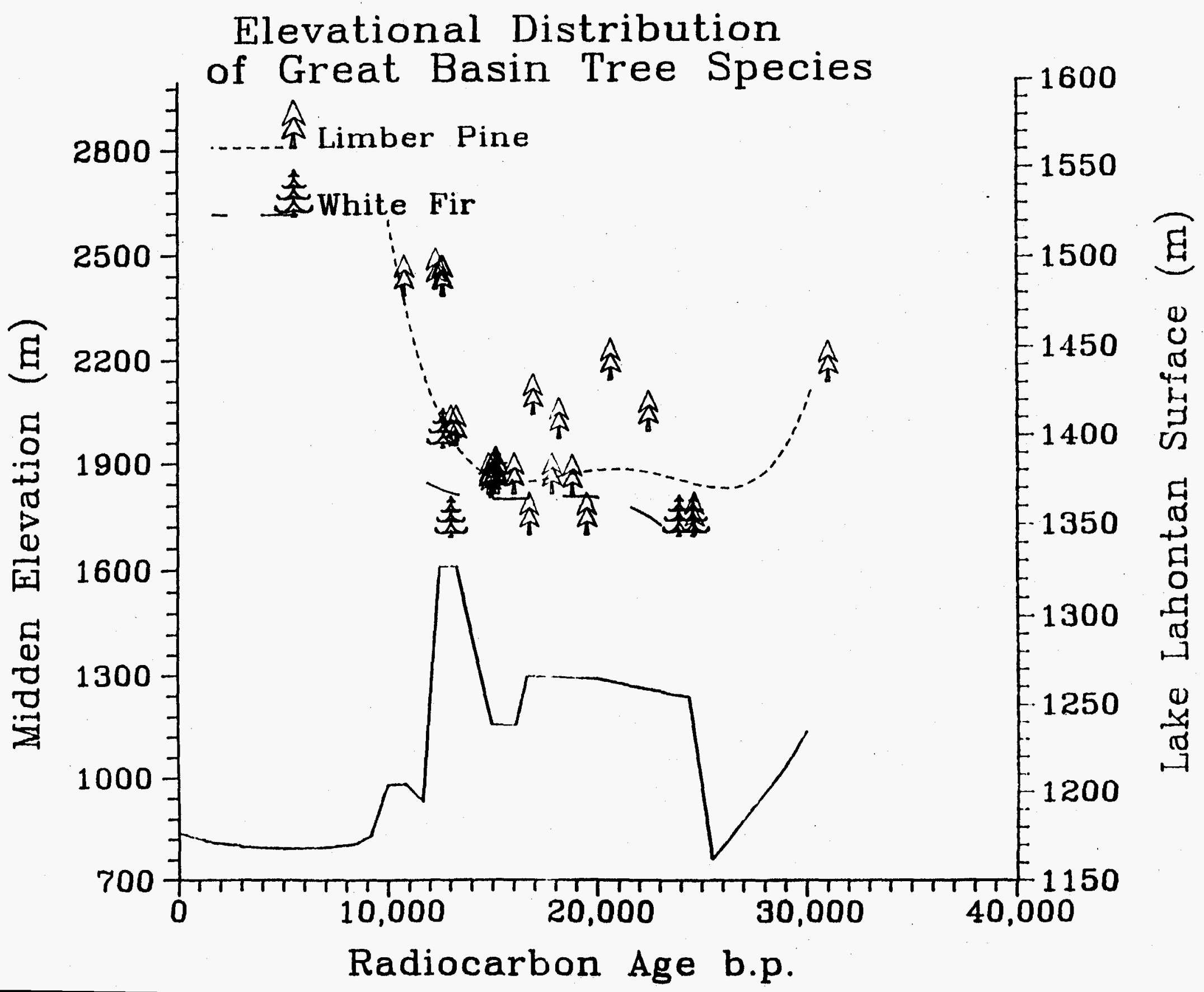




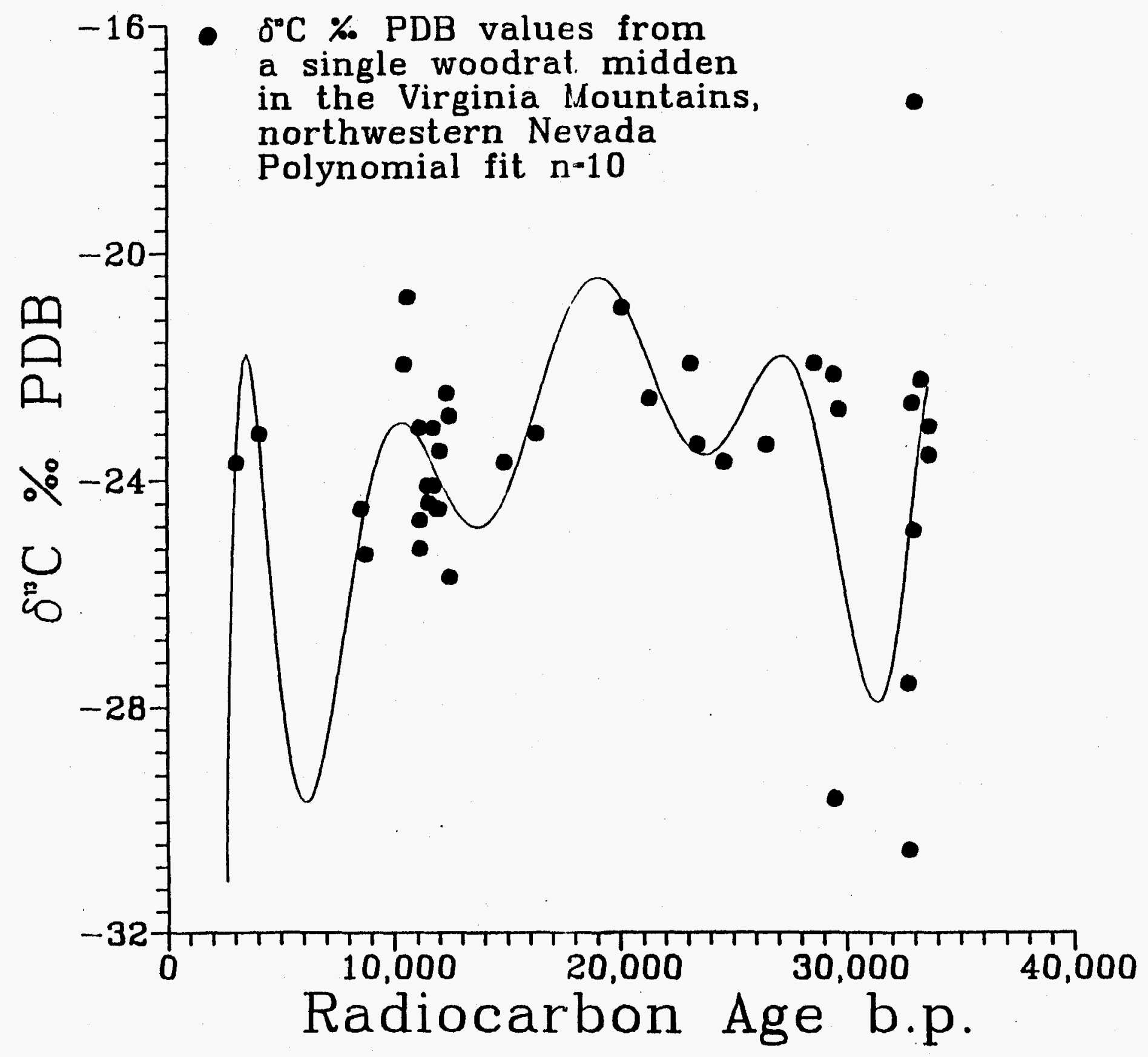




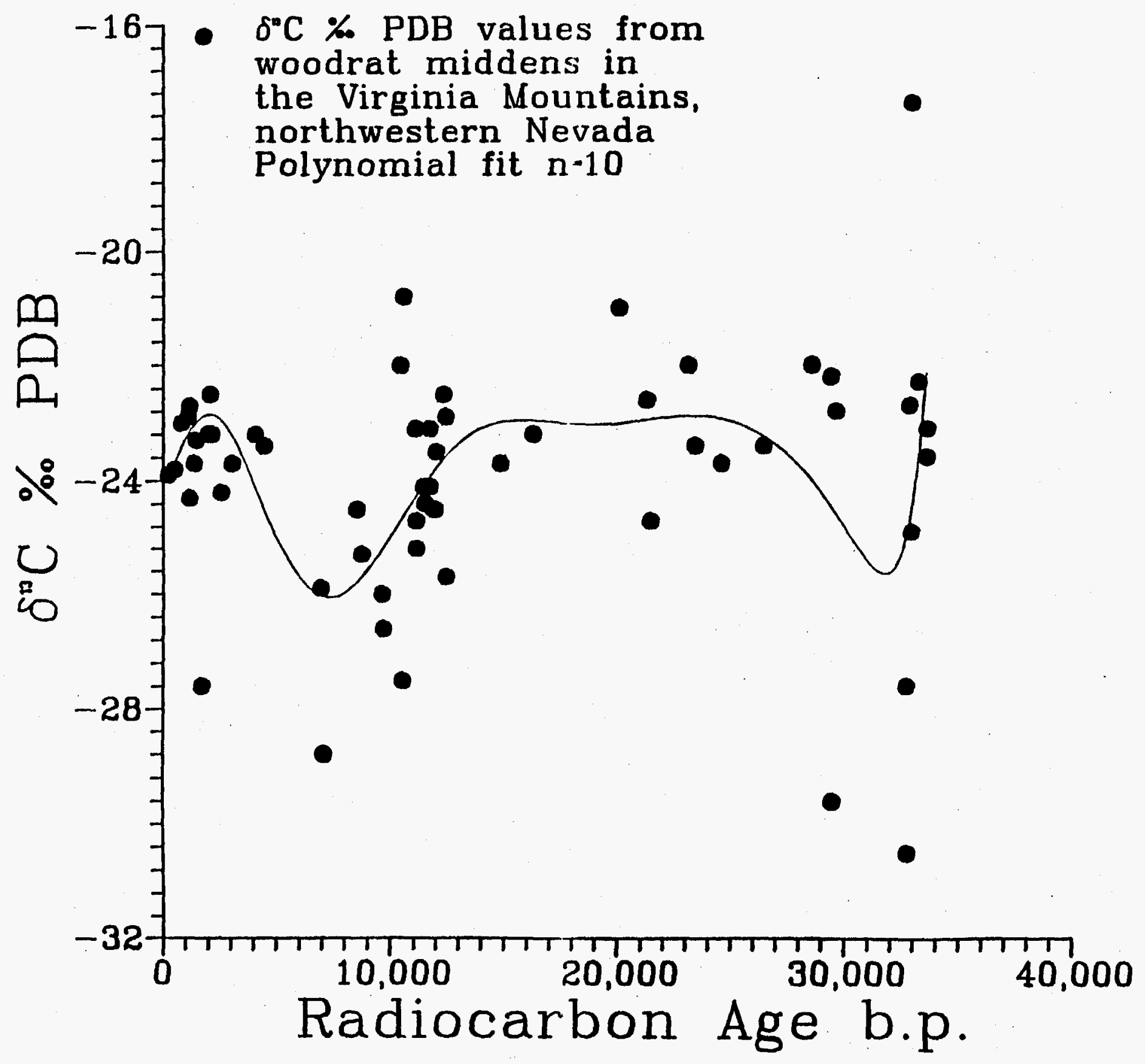




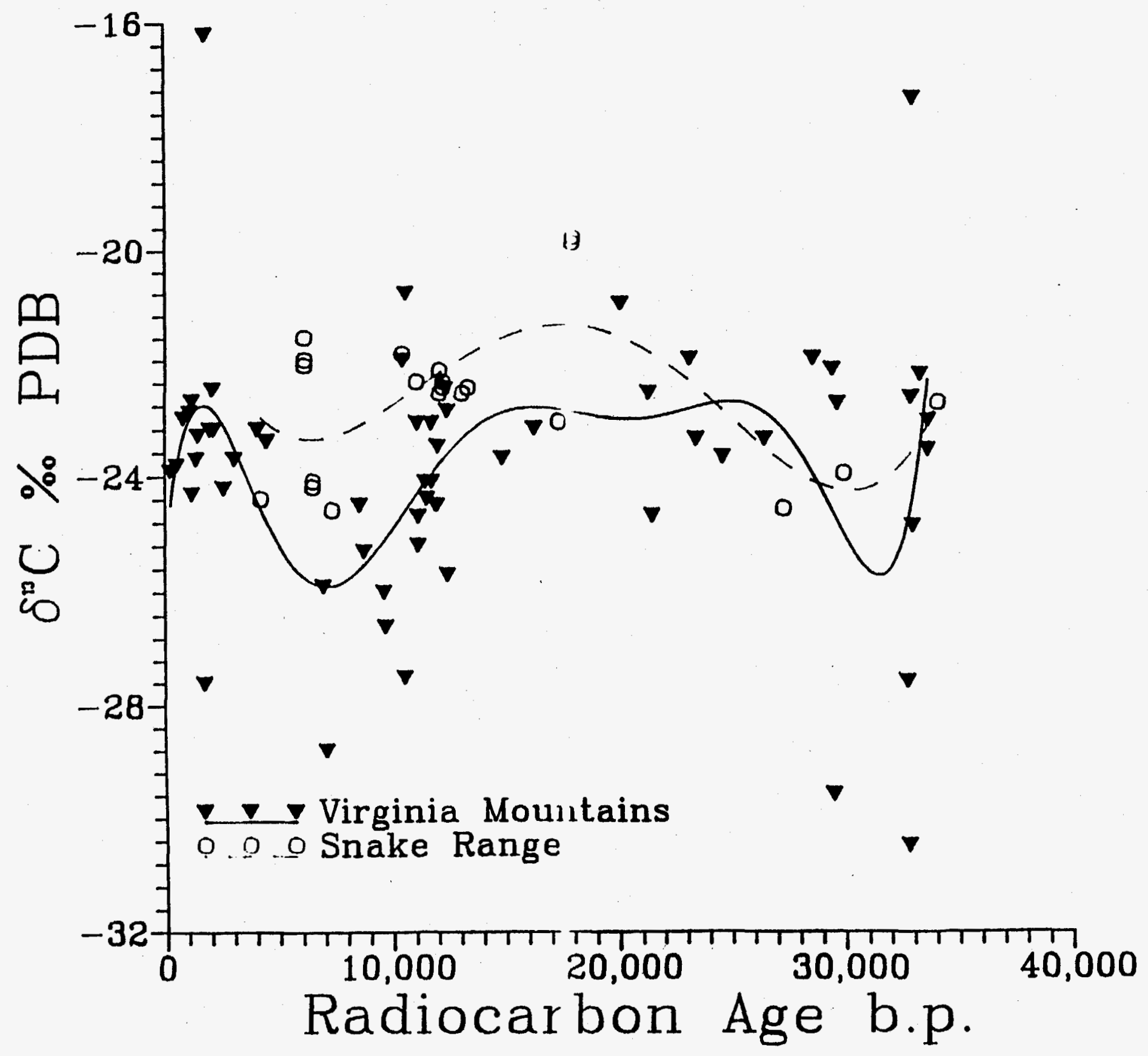




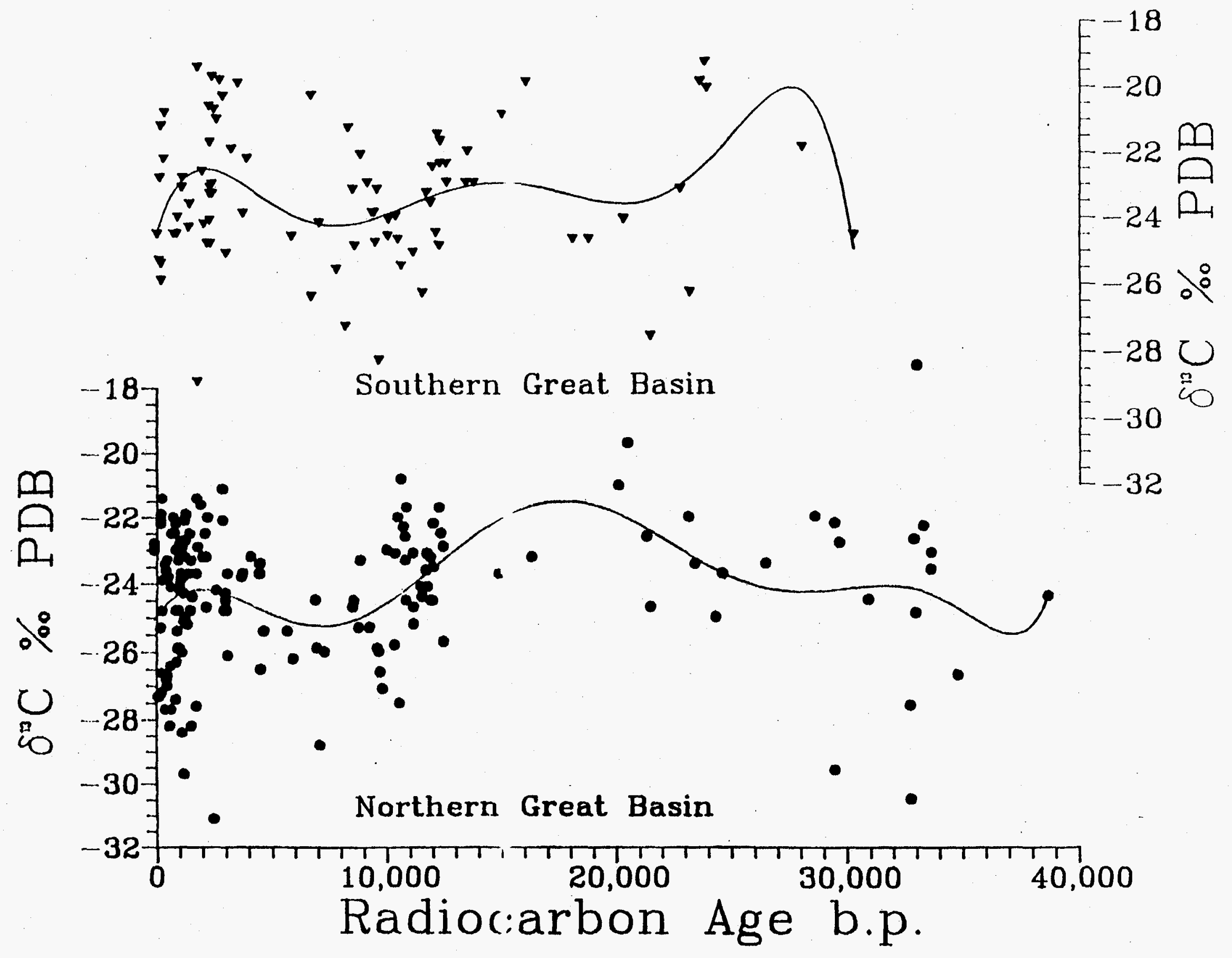




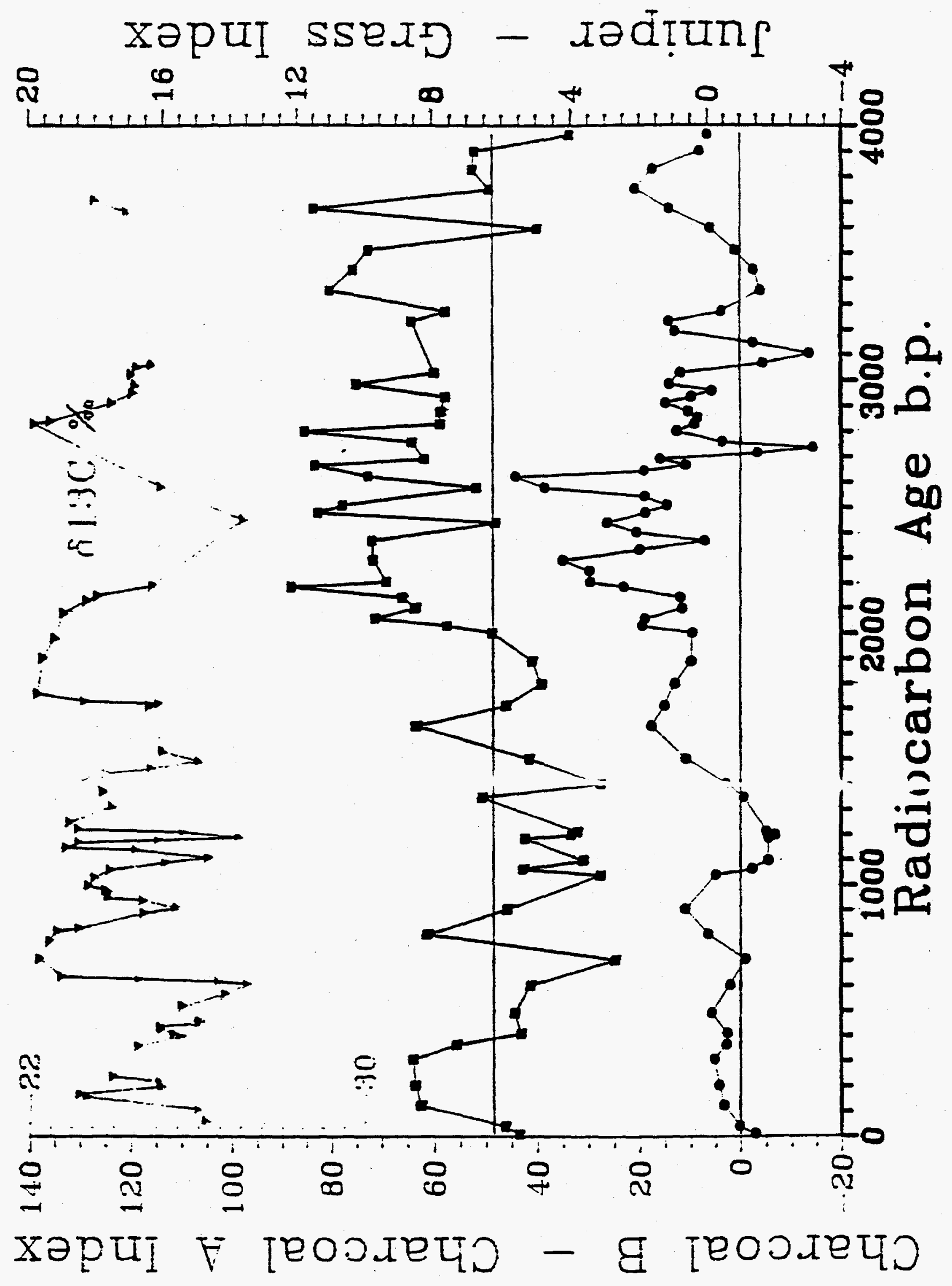


squetd uәpptW UoIf gđd \% ग.

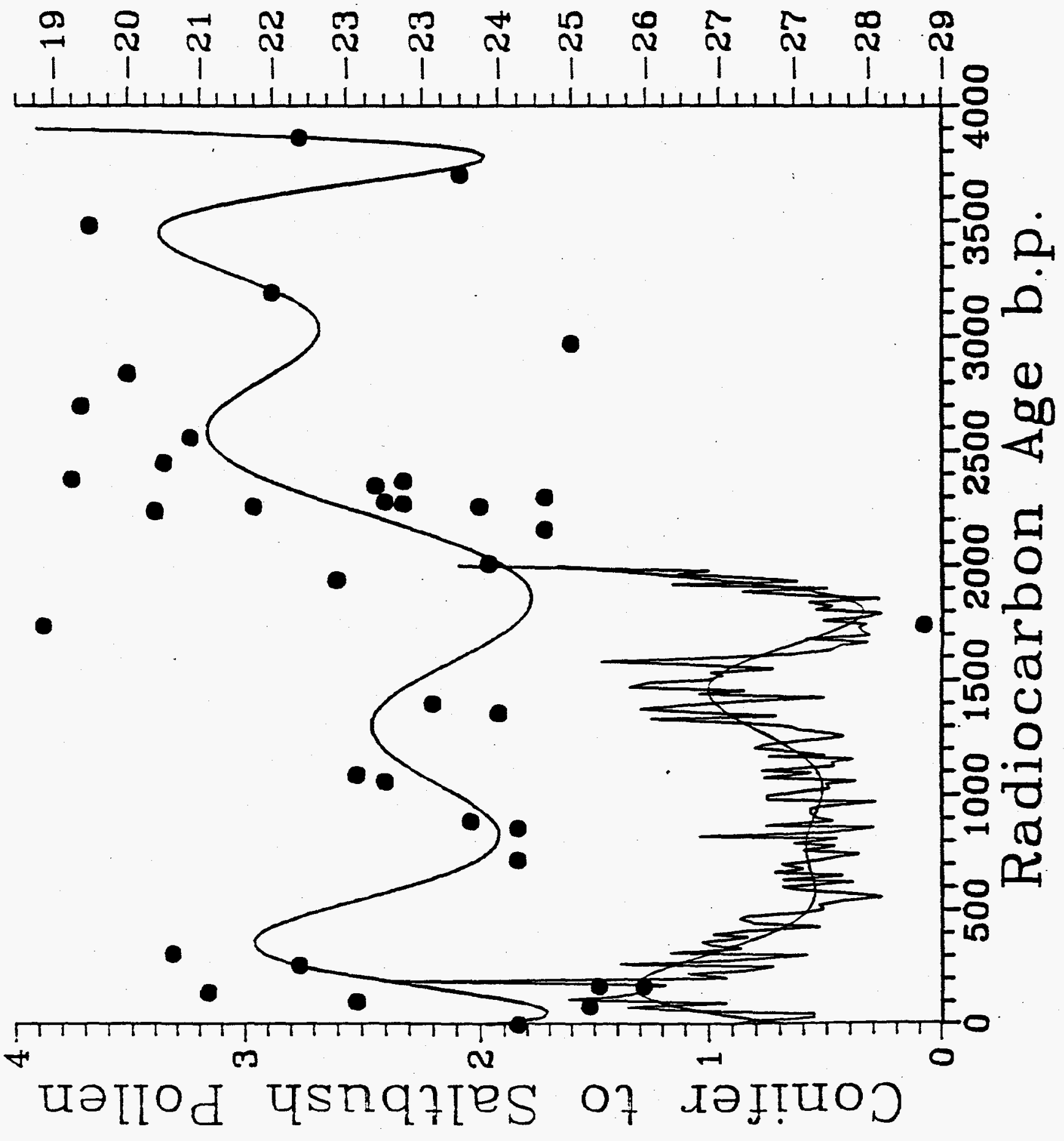

